\title{
16. PLIOCENE-PLEISTOCENE VARIATIONS IN ARAGONITE CONTENT AND PLANKTONIC OXYGEN-ISOTOPE RECORD IN BAHAMIAN PERIPLATFORM OOZE, HOLE 633A ${ }^{1}$
}

\author{
André W. Droxler, ${ }^{2}$ Christopher H. Bruce, ${ }^{3}$ William W. Sager, ${ }^{4}$ and David H. Watkins ${ }^{5}$
}

\begin{abstract}
Hole 633A was drilled in the southern part of Exuma Sound on the toe-of-slope of the southeastern part of Great Bahama Bank during ODP Leg 101. The top $55 \mathrm{~m}$, collected as a suite of six approximately 9.5 -m-long hydraulic piston cores, represents a Pliocene-Pleistocene sequence of periplatform carbonate ooze, a mixture of pelagic calcite (foraminifer and coccolith tests), some pelagic aragonite (pteropod tests), and bank-derived fine aragonite and magnesian calcite. A 1.6-m.y.-long hiatus was identified at 43.75 mbsf using calcareous nannofossil biostratigraphy and magnetostratigraphy.

The 43.75-m-thick periplatform sequence above the hiatus is a complete late Pliocene-Quaternary record of the past $2.15 \mathrm{~m} . \mathrm{y}$. The $\delta^{18} \mathrm{O}$ curve, primarily based on Globigerinoides sacculifera, clearly displays high-frequency/low-amplitude cycles during the early Pleistocene and low-frequency/high-amplitude cycles during the middle and late Pleistocene. Variations in aragonite content in the fine fraction of the periplatform ooze show a cyclic pattern throughout the Pleistocene, as previously observed in piston cores of the upper Pleistocene. These variations correlate well with the $\delta^{18} \mathrm{O}$ record: high aragonite corresponds to light interglacial $\delta^{18} \mathrm{O}$ values, and vice versa. Comparison of the $\delta^{18} \mathrm{O}$ record and the aragonite curve helps to identify 23 interglacial and glacial oxygen-isotope stages, corresponding to 10.5 aragonite cycles (labeled $A$ to $K$ ) commonly established during the middle and late Pleistocene ( 0.9 Ma-present). Strictly based on the aragonite curve, another 11 aragonite cycles, labeled $L$ to $V$, were identified for the early Pleistocene $(0.9$ to $1.6 \mathrm{Ma}$ ). Mismatches between the $\delta^{18} \mathrm{O}$ record and the aragonite curve occur mainly at some of the glacial-to-interglacial transitions, where aragonite increases usually lag behind $\delta^{18} \mathrm{O}$ depletion. When one visually connects the minima on the Pleistocene aragonite curve, low-frequency $(0.4$ to 0.5 m.y.) supercycles seem to be superimposed on the high-frequency cycles. The timing of this supercycle roughly matches the timing of the Pleistocene carbonate preservation supercycles described in the Pacific, Indian, and Atlantic oceans. Mismatches between aragonite and $\delta^{18} \mathrm{O}$ cycles are even more obvious for the late Pliocene (1.6 to $2.15 \mathrm{Ma}$ ). Irregular aragonite variations are observed for the late Pliocene, although after the onset of late Pleistocene-like glaciations in the North Atlantic Ocean $2.4 \mathrm{~m}$.y. ago the $\delta^{18} \mathrm{O}$ record has shown a mode of high-frequency/low-amplitude cycles. Initiation of climatically induced aragonite cycles occurs only at the Pliocene-Pleistocene transition, $1.6 \mathrm{~m} . y$. ago. After that time, aragonite cycles are fully developed throughout the Quaternary.

The 11-m-thick periplatform sequence below the hiatus represents a lower Pliocene interval between 3.75 and 4.45 Ma. The bottom half (4.25-4.45 Ma) has a fairly constant, high aragonite content (averaging $60 \%)$ and high sedimentation rates $(28 \mathrm{~m} / \mathrm{m} . \mathrm{y}$.) and corresponds to the end of the prolonged early Pliocene interglacial interval (4.1-5.0 $\mathrm{Ma})$, established as a worldwide high sea-level stand. The second half (3.75-4.25 Ma), in which aragonite content decreases by successive steps, paralleled by a gradual $\delta^{18} \mathrm{O}$ enrichment in Globigerinoides sacculifera and low sedimentation rates $(10 \mathrm{~m} / \mathrm{m} . \mathrm{y}$.), corresponds to the climatic deterioration established worldwide between 4.1 and $3.8 \mathrm{Ma}$, to a decrease of carbonate preservation observed in the equatorial Pacific Ocean, and to a global sea-level decline. Dolomite, a ubiquitous secondary component in the lower Pliocene, is interpreted as being authigenic and possibly related to diagenetic transformation of primary bank-derived fine magnesian calcite.

Transformation of the primary mineralogical composition of the periplatform ooze was evidently minor, as the sediments have retained a detailed record of the Pliocene-Pleistocene climatic evolution. Clear evidence of diagenetic transformations in the periplatform ooze includes (1) the disappearance of magnesian calcite in the upper $20 \mathrm{~m}$ of Hole $633 \mathrm{~A}$, (2) the occurrence of calcite overgrowths on foraminiferal tests and microclasts at intermittent chalky core levels, and (3) the ubiquitous presence of authigenic dolomite in the lower Pliocene.
\end{abstract}

\section{INTRODUCTION}

Periplatform ooze separating turbidite layers of lime mud or sand and deposited in the vicinity of shallow carbonate banks is a mixture of pelagic ooze (coccoliths and foraminifers composed of calcite [less than $4 \mathrm{~mol} \% \mathrm{MgCO}_{3}$ ] and pteropods composed of aragonite) and a variable proportion of bank-derived

\footnotetext{
${ }^{1}$ Austin, J. A., Jr., Schlager, W., et al., 1988. Proc. ODP, Sci. Results, 101: College Station, TX (Ocean Drilling Program).

2 Department of Geology and Geophysics, Rice University, P.O. Box 1892, Houston, TX 77251.

${ }^{3}$ Department of Geology, Oxygen Isotope Laboratory, University of South Carolina, Columbia, SC 29208.

4 Department of Oceanography, Texas A\&M University, College Station, TX 77843.

5 Department of Geology, University of Nebraska, 330 Bessey Hall, Lincoln, NE 68588-0340.
}

fine aragonite and magnesian calcite (more than $4 \mathrm{~mol} \% \mathrm{MgCO}_{3}$ ) (Schlager and James, 1978). Sea-level fluctuations, which, to a great extent, influence the sediment production and export from the shallow banks, are preserved in the mineral composition of the periplatform ooze owing to the different carbonate mineralogy of pelagic and bank-derived components. Because aragonite and magnesian calcite are metastable relative to calcite, their degree of preservation or removal by dissolution at the seafloor is related to variations of the carbonate saturation state within the overlying water masses, and this may overprint the primary mineralogical input signal. Furthermore, the admixture of the metastable carbonate phases (aragonite and magnesian calcite) relative to pure pelagic calcite gives periplatform ooze a greater diagenetic potential than pure pelagic calcitic ooze.

In the Bahamas, upper Quaternary periplatform ooze shows cyclic variations of aragonite content in the fine fraction $(<62$ $\mu \mathrm{m})$, in addition to cyclic variations of total carbonate and quartz 
content (Supko, 1963; Kier and Pilkey, 1971; Droxler et al., 1983; Boardman et al., 1986; Slowey, 1985). This is also true on the Nicaraguan Rise (Caribbean Sea) and in the Maldives (Indian Ocean) (Droxler, 1986a). Aragonite cycles, as well as carbonate-terrigenous cycles, are closely correlated with the oxygen-isotope record of planktonic foraminifers (Droxler et al., 1983; Boardman et al., 1986; Droxler, 1986a) and thus may be climatically induced cycles corresponding to the long series of glacial-interglacial alternations observed since the onset of major glaciation in the North Atlantic Ocean 2.4 m.y. ago (e.g., Shackleton et al., 1984). Although the relationship between climatic variations and aragonite cycles in periplatform ooze is clear during the late Quaternary, the real causes of these aragonite cycles are still a subject of controversy (see Droxler and Schlager, 1985b; Droxler, 1986b; Boardman and Neumann, 1985, 1986). We have interpreted aragonite cycles as a dissolutionpreservation imprint on an input signal of bank-derived aragonite related to the flooding and exposure of the shallow banks. According to this interpretation, aragonite cycles in intermediate water masses would be analogous to the glacial carbonate dissolution cycles of the deep Atlantic. Another group of researchers, led by Boardman and Neumann, argues that the aragonite cycles are a pure input signal of bank-derived aragonite related to the flooding and exposure of the shallow banks, and therefore a detailed sea-level indicator.

Coring in the Bahamas during Leg 101 of the Ocean Drilling Program recovered thick undisturbed sequences of periplatform ooze with the hydraulic piston corer (HPC). This was a unique opportunity to extend the available 12 - to $18-\mathrm{m}$ penetrations of this ooze by regular piston coring (corresponding in age to late or middle Pleistocene). By recovering thicker periplatform sequences, three new questions could be addressed: (1) How did the climatically induced aragonite cycles, well-established during middle to late Pleistocene, evolve during the early Pleistocene and the Pliocene? How do they record major climatic events (e.g., the onset of major glaciations around the North Atlantic Ocean at $2.4 \mathrm{Ma}$ )? (2) How well does the aragonite content in the fine fraction correlate with the oxygen-isotope record on planktonic foraminifers for the entire Pliocene-Pleistocene? (3) How much has the primary depositional record been modified by early burial diagenesis, owing to the presence of metastable aragonite and magnesian calcite components in the periplatform ooze? In this regard, some research in the Bahamas has predicted that aragonitic components would be rapidly replaced by more stable carbonate phases such as calcite and perhaps dolomite.

\section{SITE LOCATION AND DESCRIPTION}

Hole 633A was drilled in the southern part of Exuma Sound on the toe-of-slope of the Great Bahama Bank, in $1681 \mathrm{~m}$ water depth (Fig. 1). Only the top $55 \mathrm{~m}$ of Hole 633A was studied in this research program. This interval corresponds almost exclusively to lithologic Unit I, defined in Austin, Schlager, et al. (1986) as a periplatform-ooze sequence with cyclic variations in color and a few scattered 1 - to 10 -cm-thick calcareous turbidite layers. Considering the proximal position of Hole $633 \mathrm{~A}$, the fine-grained turbidites in Unit I are unusually thin. These characteristics can be explained by the location of the site on a topographic high that rises 20 to $40 \mathrm{~m}$ above the surrounding seafloor and could be caused by progradation of a spur of the gullied slope or by large-scale slumping prior to the deposition of Unit I (Austin, Schlager, et al., 1986).

\section{METHODS}

\section{Sediment Sampling and Analyses}

The top $55 \mathrm{~m}$ of Hole $633 \mathrm{~A}$ was sampled every $10 \mathrm{~cm}$; care was taken to avoid sampling turbidite layers and zones with obvious reworking or disturbed features. Each $10-\mathrm{cm}^{3}$ sediment sample was dried in an oven at $60^{\circ} \mathrm{C}$, weighed, and suspended in distilled water $(\mathrm{pH} 8)$. The coarse fraction of the sediment was separated from the fine fraction through a $62-\mu \mathrm{m}$-mesh sieve and then dried at $60^{\circ} \mathrm{C}$ and weighed again. The fine fraction (less than $62 \mu \mathrm{m}$ ) was left to stand in distilled water for a day or two until the particles were completely settled, and was then dried at $60^{\circ} \mathrm{C}$. The coarse fraction was used to establish the Menardii Complex stratigraphy, to estimate the degrees of cementation and overgrowth, and to pick monospecific samples of planktonic foraminifers-Globigerinoides sacculifera and Globigerinoides rubra (pink)-for oxygenisotope analyses. The fine fraction was used for carbonate-mineralogy analyses by X-ray diffraction and for carbonate-content analyses by carbonate bomb. Bulk samples at 0.5 -m intervals were used to establish the calcareous nannofossil biostratigraphy by smear slide and SEM analyses, and oriented samples were taken at $0.5-$ to $1-\mathrm{m}$ intervals to develop magnetostratigraphy; analyses were conducted on a cryogenic magnetometer made available to us at the University of Texas at Austin.

Carbonate Content in Fine Fraction $(<62 \mu \mathrm{m})$

The carbonate-bomb method was used to determine the total carbonate content of the fine fraction in each sample from the $\mathrm{CO}_{2}$ pressure generated by dissolving the carbonate fraction in $50 \%$ concentrated $\mathrm{HCl}$ (Müller and Gastner, 1971). The pressure of $\mathrm{CO}_{2}$ released by the fraction of the carbonate with the acid was compared with pressure released by an equal amount of $100 \% \mathrm{CaCO}_{3}$ standard. Accuracy of the method for marine sediments remained within $\pm 2 \%$ for $\mathrm{CaCO}_{3}$ values ranging between $5 \%$ and $95 \%$ (Birch, 1979).

\section{Carbonate Mineralogy $(<62 \mu \mathrm{m})$}

Relative proportions of the different carbonate minerals were quantified by X-ray-diffraction analyses. Each sample of fine sediment was dried at $60^{\circ} \mathrm{C}$, ground for less than a minute by hand in an agate mortar, sieved to obtain an agglomerate of $<62 \mu \mathrm{m}$ particles, and packed with a spatula into an aluminum sample holder. The effects of particle size and grinding are minimized through these procedures (Milliman, 1974). Each sample was then analyzed using a Norelco-Philips X-ray diffractometer at $30 \mathrm{KV}$ and $20 \mathrm{Ma}$, through a scan from $32^{\circ}$ to $25^{\circ}$, at low scanning speed of $0.25^{\circ} /$ minute for optimal resolution. Areas under the aragonite peak, the dolomite peak (if present), the calcite peaks (calcite and magnesian calcite = total calcite), and under the half lower $2 \theta$ angles of the calcite peak (since calcite was always larger than magnesian calcite) were measured by planimeter. The calcite area was calculated by doubling its measured half-peak area and the magnesian calcite area by subtracting the area of calcite from the measured area under the total calcite peaks. The aragonite portion in each sample was calculated with an accuracy of better than $5 \%$ from a calibration curve (Droxler, 1984). Reproducibility of the method used to separate calcite from magnesian calcite is within a measured maximum discrepancy of $9 \%$. Because of the linear relationship between dolomite and calcite (Milliman, 1974 , p. 26), the dolomite proportion was calculated by a ratio of the dolomite-peak area and the total area of both dolomite and total calcite peaks.

\section{Stratigraphy}

Calcareous-Nannofossil Biostratigraphy. Nannofossil assemblages were examined using light microscopy on smear slides of raw sediment and on gravitationally concentrated samples. Biostratigraphic age determinations were based on first- and last-occurrence datums using the geochronologic assignments of Berggren et al. (1985). In general, nannofossil abundances in the smear slides of raw sediment varied from approximately $70 \%$ to less than $5 \%$, with platform-derived debris composing much of the rest of the sample. Samples from Hole 633A exhibited a notable covariance of nannofossil preservation and abundance. Preservation was excellent in Quaternary nannofossil oozes, which contained little or no significant platform-derived components. The original forms of the taxa were retained, with infilling of the central area only rarely occurring in taxa such as gephyrocapsids. Poorer preservation was typical of Quaternary and Pliocene periplatform oozes, with $24 \%-40 \%$ nannofossils in the smear slides. Overgrowths were the most common diagenetic alteration of larger nannofossils in these samples. Etching of smaller coccoliths was common. Samples with less than $10 \%$ nannofossil material tended to be very poorly preserved. Overgrowth of discoasters and large placoliths was intense in these samples, commonly obscuring taxonomic affinities. Most of the more delicate taxa have been destroyed by dissolution. 


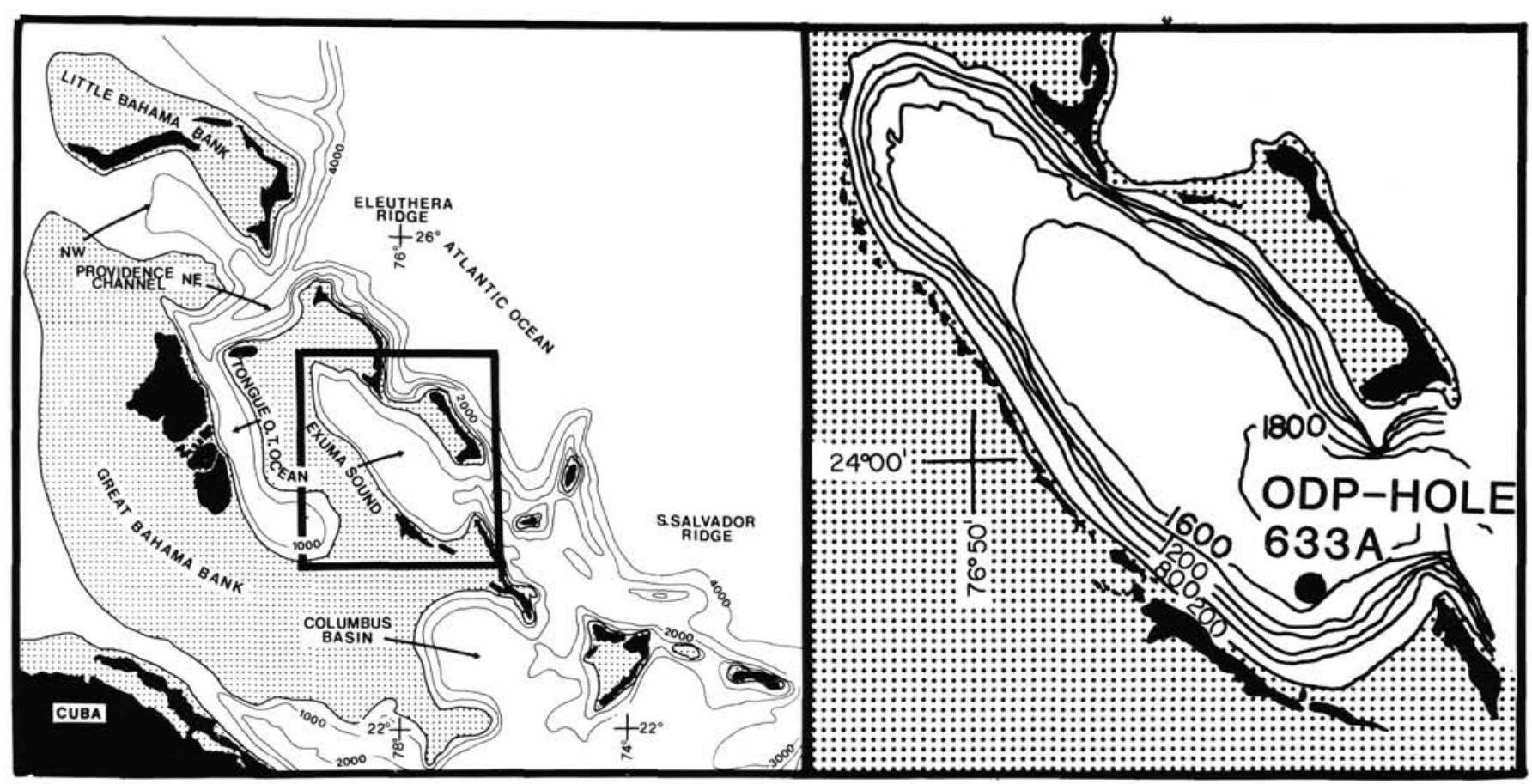

Figure 1. Location maps, Hole 633A. Contours (in meters) after King (1969); insert modified from Crevello and Schlager (1980). Dotted pattern delineates carbonate banks shallower than $20 \mathrm{~m}$.

Globorotalia menardii Complex. The Globorotalia menardii Complex, referred to later in this discussion as Menardii Complex, was established by observing the $>300 \mu \mathrm{m}$ size fraction to determine presence or absence of the three subspecies of the Menardii Complex: Globorotalia menardii, Globorotalia menardii tumida, Globorotalia menardii flexu$o s a$. The different zones of the Menardii Complex stratigraphy (defined by Ericson and Wollin, 1966) were identified in Hole 633A from zone Z down to possibly zone $\mathrm{P}$.

Magnetostratigraphy. Magnetic characteristics of 102 oriented samples from Hole 633A were measured with an SCT cryogenic magnetometer. The NRM intensities of these samples varied systematically through more than two orders of magnitude. Samples in the upper $30 \mathrm{~m}$ of Hole $633 \mathrm{~A}$ were the most strongly magnetic, having NRM intensities as high as $9 \times 10^{-3} \mathrm{~A} / \mathrm{m}$. In the rest of the hole, the NRM intensities averaged $5 \times 10^{-5} \mathrm{~A} / \mathrm{m}$. Stable remanent magnetic directions were determined by stepwise alternating-field demagnetization. Because many of the samples were relatively weakly magnetic, each value of the remanent direction was determined by averaging at least six individual measurements. In this manner, random scatter from thermal and electrical noise in the magnetometer was reduced. An interpretation of magnetic polarity was made for each sample using its stable magnetic inclination. Normally polarized samples yielded inclinations in the average of $44^{\circ}$ downward (the geocentric axial dipole inclination for Hole 633A), whereas reversely polarized samples showed inclinations of about $44^{\circ}$ upward.

\section{Oxygen Isotopes}

Oxygen isotopes were analyzed on hand-picked samples of Globigerinoides sacculifera down to Section 633A-6H-1 (47 m sub-bottom), and of Globigerinoides rubra (pink) occasionally in the upper $7 \mathrm{~m}$ of Hole $633 \mathrm{~A}$, using the same $10-\mathrm{cm}$ spaced sample whose fine fraction was used for mineralogical studies. For each sample, 10 to 20 foraminifer tests were picked in a narrow size fraction between 300 and $350 \mu \mathrm{m}$, cleaned ultrasonically to remove any calcareous mud clinging to the tests, dried at $60^{\circ} \mathrm{C}$, and roasted at $370^{\circ}-380^{\circ} \mathrm{C}$ for $1 \mathrm{hr}$ under vacuum. They were then reacted at $60^{\circ} \mathrm{C}$ with excess $100 \% \mathrm{H}_{3} \mathrm{PO}_{4}$, and the $\mathrm{CO}_{2}$ gas was analyzed in one of the two mass spectrometers (VG SIRA 24 and VG Micromass 602) at the Stable Isotope Laboratory of the University of South Carolina. Results are reported relative to the PDB standard. Analytical precision on standards and duplicated samples was $0.15 \%$ and $0.25 \%$, respectively.

\section{RESULTS}

\section{Establishment of a Pliocene Hiatus}

\section{Calcareous-Nannofossil Biostratigraphy}

Examination of the top $55 \mathrm{~m}$ of Hole $633 \mathrm{~A}$ for calcareousnannofossil biostratigraphy shows that the Quaternary and upper Pliocene are quite complete through the Calcidiscus macintyrei Subzone (CN12d) down to $43.75 \mathrm{~m}$ (Section 101-633A-5H-5), where the CN12d Subzone lies directly on the Amaurolithus tricorniculatus Zone (CN10). The hiatus includes Subzones CN11 to $\mathrm{CN12}$ and may also include the upper part of $\mathrm{CN} 10$ as well (CN10c?). The generally poor preservation of the nannofossil assemblage in this part of Core 101-633A-6H makes it difficult to determine exactly how much of uppermost Zone CN10 is missing. Figure 2 shows the timing of the nannostratigraphy of the Quaternary-Pliocene interval according to Berggren et al. (1985). The age of the sediment just below the hiatus is not well constrained and could range between 3.8 and $4.4 \mathrm{Ma}$. On the other hand, sediment age just above the hiatus can be estimated to be confined between 2.1 and $2.2 \mathrm{Ma}$., because a $0.3-\mathrm{m}$.y.long $\mathrm{CN} 12 \mathrm{~d}$ Subzone is only partially represented. The Pliocene hiatus therefore represents a time interval as long as 1.7 to $2.3 \mathrm{~m} . \mathrm{y}$.

Figure 3 shows an age vs. depth curve based on the coccolith subzones for Hole 633A. The Quaternary is defined by the beginning of the Gephyrocapsa caribbeanica Subzone (CN13b) at $1.6 \mathrm{~m}$.y. The average sedimentation rate of $23 \mathrm{~m} / \mathrm{m}$.y. does not display any noticeable break at that time boundary. During the late Pliocene, the average sedimentation rate dropped to $12 \mathrm{~m}$ / m.y., about half that of the Quaternary. Below the hiatus, the sedimentation rate in Core $101-633 \mathrm{~A}-6 \mathrm{H}$ is difficult to estimate, because its sediment is within a single coccolith zone (Amaurolithus tricorniculatus Zone.) However, by extrapolation with the biostratigraphy of older sediment in Core 101-633A-7H, the sedimentation rate can be roughly estimated as $28 \mathrm{~m} / \mathrm{m}$.y. 


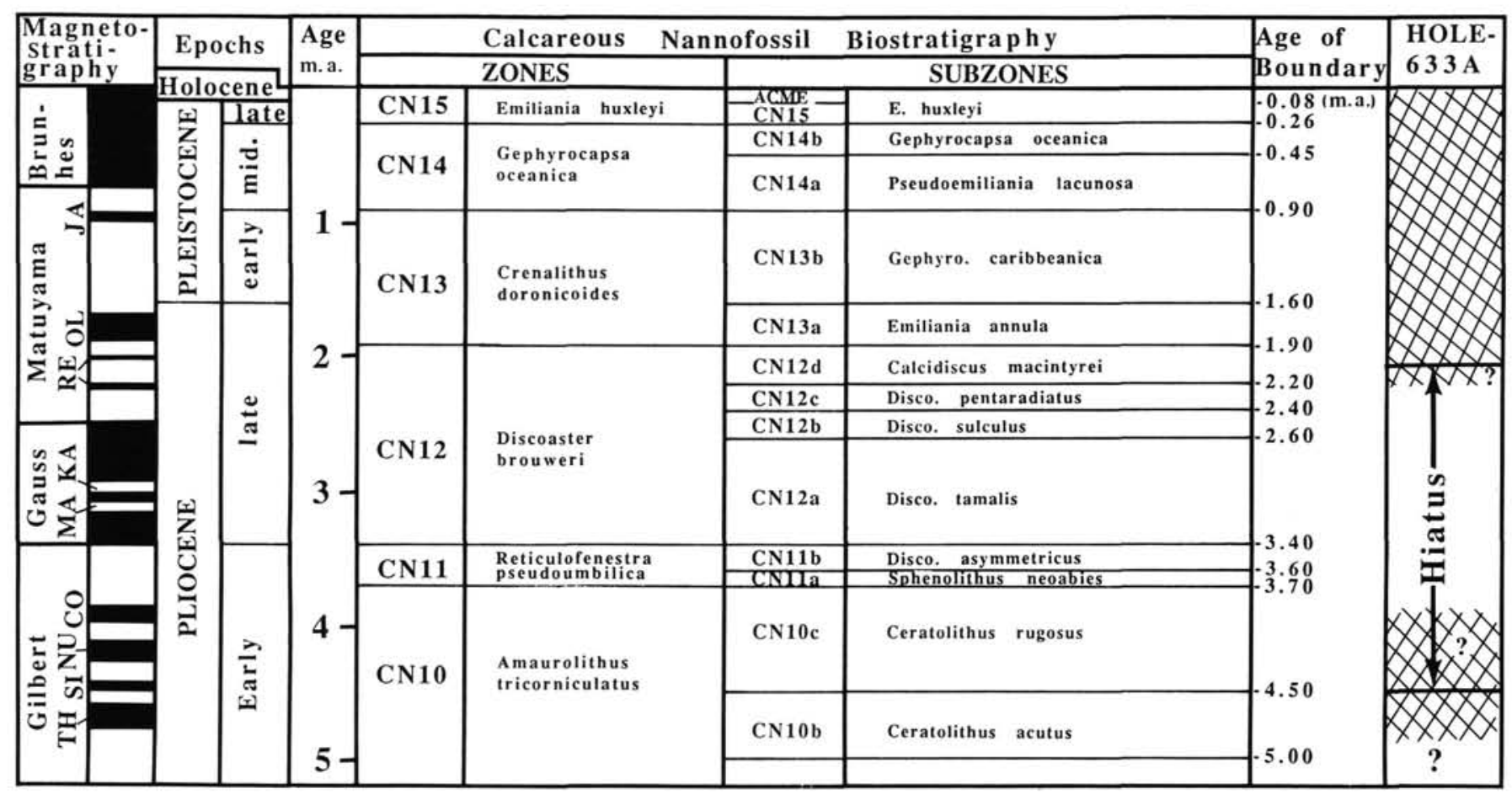

Figure 2. Top $70 \mathrm{~m}$ of Hole 633A placed on a time scale based on general calcareous-nannofossil biostratigraphy (from Berggren et al., 1985) and on general magnetostratigraphy (from Harland et al., 1982). Minimum and maximum possible extension of Pliocene hiatus in Hole 633A is also shown.

\section{Magnetostratigraphy}

The hiatus at 43.75 mbsf, well defined by biostratigraphy, is recorded by the absence of the Gauss normal Chron in the variations through time of the paleomagnetic inclinations (Fig. 4). Above the hiatus are the Brunhes and Matuyama Chrons, and the switch from normal to reverse inclination is at $16.75 \mathrm{mbsf}$. Jaramillo, Olduvai, and possibly Reunion normal events are observed within the Matuyama reversed Chron. The earliest 0.2 m.y. of the Matuyama Chron seems to be missing. Below the hiatus, the four normal events within the Gilbert reversed Chron (Cochiti, Nunivak, and Sidufjall, as well as the top of the Thvera) are observed.

By plotting the age of the successive boundaries of the paleomagnetic events (Harland et al., 1982) on an age vs. depth curve (Fig. 4), downcore variations of sedimentation rate can be calculated, and the timing of the hiatus can be better constrained. Above the hiatus, sedimentation rate increases by a factor of 2 at around 1.65 Ma, in support of the age vs. depth curve based on calcareous-nannofossil biostratigraphy (Fig. 3). By extrapolating the calculated sedimentation rate of 11 to $12 \mathrm{~m} / \mathrm{m}$.y. between 1.6 and $2.2 \mathrm{Ma}$, the age of the sediment just above the hiatus is estimated to be $2.15 \mathrm{Ma}$. The occurrence of the four events within the Gilbert Chron helps in calculating the variation of sedimentation rate during the early Pliocene. This could not be done using nannofossil biostratigraphy because of low resolution owing to the poor preservation of the material. The highest sedimentation rate during the Pliocene-Pleistocene (28 $\mathrm{m} / \mathrm{m}$.y.) was recorded during the period before $4.25 \mathrm{Ma}$. It drops by a factor of almost 3 to $10 \mathrm{~m} / \mathrm{m}$.y. between 4.25 and $3.9 \mathrm{Ma}$. By extrapolation of this low sedimentation rate, the age of the sediment just below the hiatus was estimated to be $3.75 \mathrm{Ma}$. Therefore, based in part on the nannofossil biostratigraphy but mainly on the magnetostratigraphy, the upper Pliocene hiatus corresponds to a time interval of approximately $1.6 \mathrm{~m} . \mathrm{y}$. , and the upper $55 \mathrm{~m}$ of Hole $633 \mathrm{~A}$ can be subdivided into four time intervals: (1) Holocene through upper to middle Pleistocene 0.00 0.90 Ma, 00.00-20.50 mbsf; (2) lower Pleistocene, 0.90-1.60 Ma, 20.50-36.50 mbsf; (3) upper Pliocene, 1.60-2.15 Ma, 36.5043.75 mbsf; and (4) lower Pliocene, 3.75-4.40 Ma, 43.75-55 mbsf.

\section{Pliocene-Pleistocene Variations in Lithology, Carbonate Content, Carbonate Mineralogy, and Quartz Occurrence}

Results from analyses of lithology, carbonate content, carbonate mineralogy, and quartz occurrence are organized in the four time intervals defined by nannofossil biostratigraphy and magnetostratigraphy (see previous section).

\section{Holocene Through Upper to Middle Pleistocene (Fig. 5)}

The top $20.5 \mathrm{~m}$ of Hole $633 \mathrm{~A}$ corresponds to the past 0.9 to 1.0 m.y. The timing of this interval is well constrained by nannofossil biostratigraphy, by the Menardii Complex zones, and by magnetostratigraphy. Several nannofossil zones occur in that interval. The acme zone of Emiliania huxleyi is present in the top $2 \mathrm{~m}$, therefore making it younger than $0.085 \mathrm{Ma}$ and the beginning of Emiliania huxleyi at $6.20 \mathrm{mbsf}$ dated as $0.25 \mathrm{Ma}$ (Thierstein et al., 1977). The end and beginning of the Pseudoemiliania lacunosa Subzone, close in age to $0.45 \mathrm{Ma}$ and 0.9 $\mathrm{Ma}$, respectively (Berggren et al., 1985), occur at $9.00 \mathrm{mbsf}$ and 21.5 mbsf. None of the intermediate subzones is missing. The expected Menardii Complex zones, from Z (0-0.3 mbsf, corresponding to the Holocene) to $\mathrm{T}$, are present. The boundary between the Brunhes/Matuyama Chron, dated at $0.73 \mathrm{Ma}$, occurs at 16.75 mbsf. The Jaramillo normal event (between 0.92 and $0.97 \mathrm{Ma}$ ) occurs close to $20 \mathrm{mbsf}$. Overall, this sediment is a periplatform ooze with less than $1 \%$ chalk, observed only rarely in the vicinity of turbidite layers.

Carbonate content of the fine fraction varies between $82 \%$ and $96 \%$ and shows irregular fluctuations with minima averag- 


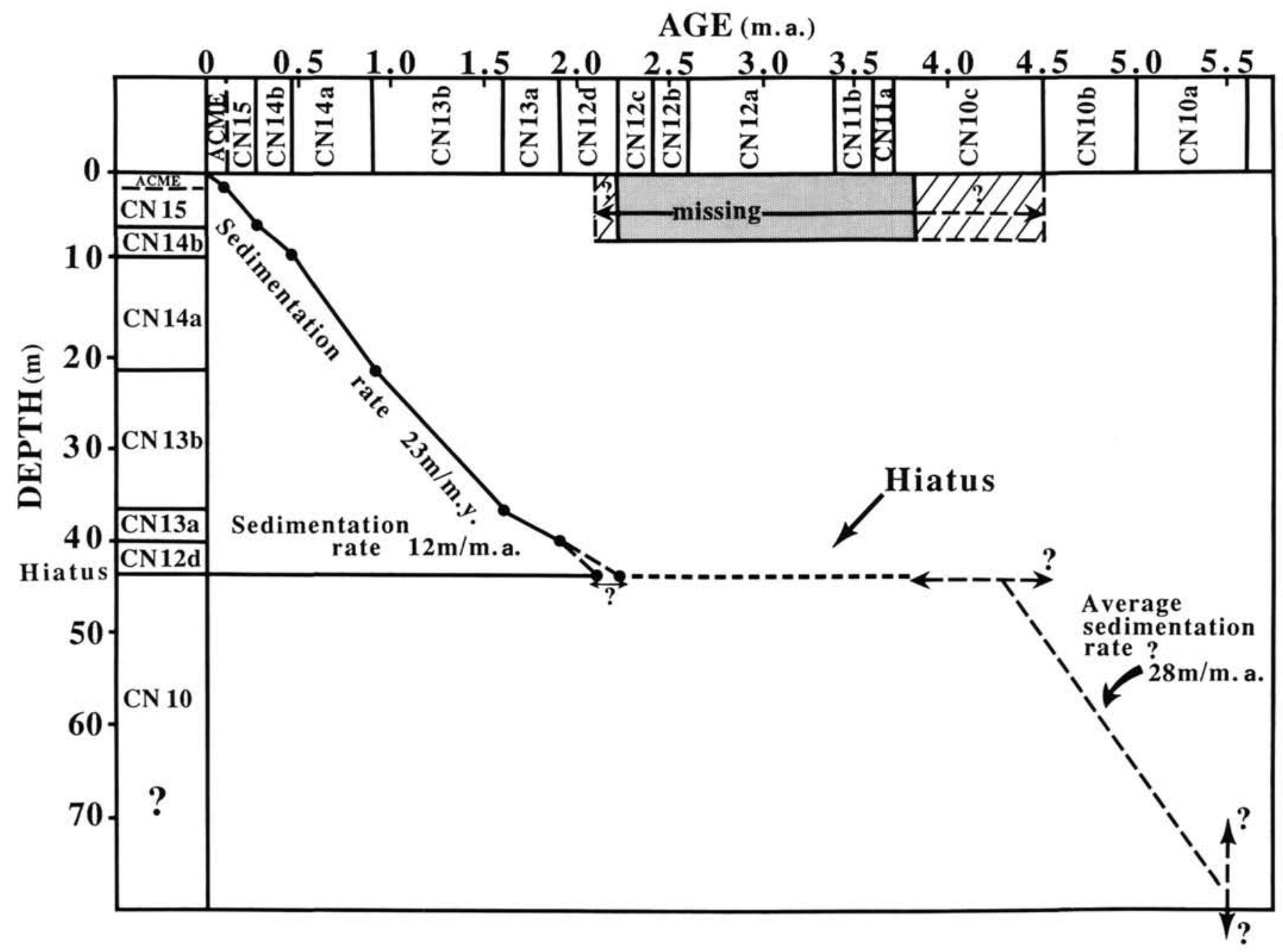

Figure 3. Age vs. depth curve for top $65 \mathrm{~m}$ of Hole 633A based on calcareous-nannofossil stratigraphy (from Berggren et al., 1985). Note the break in sedimentation rates by a factor of 2 at $1.6 \mathrm{Ma}$, from $23 \mathrm{~m} / \mathrm{m}$.y. to $12 \mathrm{~m} / \mathrm{m}$.y., the general Pliocene hiatus between 2.2 (2.1) Ma and 3.75 (4.4) Ma. The sedimentation rate below the hiatus is only a rough average estimate $(28 \mathrm{~m} / \mathrm{m} . \mathrm{y}$. $)$.

ing $87 \%$ and maxima around $95 \%$. The lowest values of carbonate content (e.g., $82 \%$ at 10.25 mbsf) correspond to clayrich layers that were observed in the middle Pleistocene section at some of the other Leg 101 sites north of Little Bahama Bank and in Exuma Sound as well as in one piston core from the Northwest Providence Channel (Slowey, 1985). Quartz, as expected, is always related to low-carbonate intervals.

The suite of carbonate minerals includes aragonite, calcite, magnesian calcite, and dolomite in the Holocene and the upper and middle Pleistocene. Aragonite and calcite are the two major components; magnesian calcite and dolomite are secondary minerals. Aragonite maxima fluctuate between $50 \%$ and $80 \%$, and aragonite minima between $5 \%$ and $40 \%$. Magnesian calcite reaches a maximum value of $15 \%$ at the top of Hole $633 \mathrm{~A}$ and gradually decreases downcore. It disappears at 6 mbsf and reappears only twice, in the two most aragonite-rich intervals (between 12.5-14 mbsf and 17.75-19.80 mbsf). Traces of dolomite appear only with the clay-rich layers and could be either detrital or diagenetic (formed by magnesium release of some of the clays).

As previously observed in piston cores (Droxler et al., 1983; Boardman et al., 1986; Slowey, 1985), aragonite content displays a regular cyclic pattern. Each cycle has an asymmetric shape representing a sharp aragonite increase followed by a more gradual decrease. These cycles have been correlated with the oxygen-isotope record from planktonic foraminifers for the past 0.35 to 0.5 m.y. (Droxler et al., 1983; Boardman et al., 1986) and are therefore interpreted as climatically induced glacial/interglacial cycles. High values of aragonite and carbonate content correspond to light $\delta^{18} \mathrm{O}$ and thus interglacial intervals, whereas low values of aragonite and carbonate content correspond to heavy $\delta^{18} \mathrm{O}$ and thus glacial intervals. In the past 0.9 to 1 m.y., 10.5 aragonite cycles can be distinguished. They are labeled from $A$ through $K$, starting at the top of Hole $633 \mathrm{~A}$, as defined in Droxler et al. (1983). Each cycle starts with the sharp aragonite increase characteristic of the glacial/interglacial transition and includes an interglacial interval and the following glacial interval. Cycle A, corresponding to the Holocene, is therefore only a half cycle. A similar continuous Holocene through upper to middle Pleistocene aragonite record was described by Slowey (1985) in a 17.5-m-long piston core from Northwest Providence Channel. The overall pattern of aragonite cycles in this piston core correlates well with those displayed in the top $21 \mathrm{~m}$ of Hole 633A.

The coarse fraction usually makes up less than $20 \%$ of the total sediment, and only partial overgrowths on the foraminifer tests are observable in some of the lowest aragonite glacial intervals, such as in cycles D, F, and $\mathrm{K}$. The average rate of sedimen- 


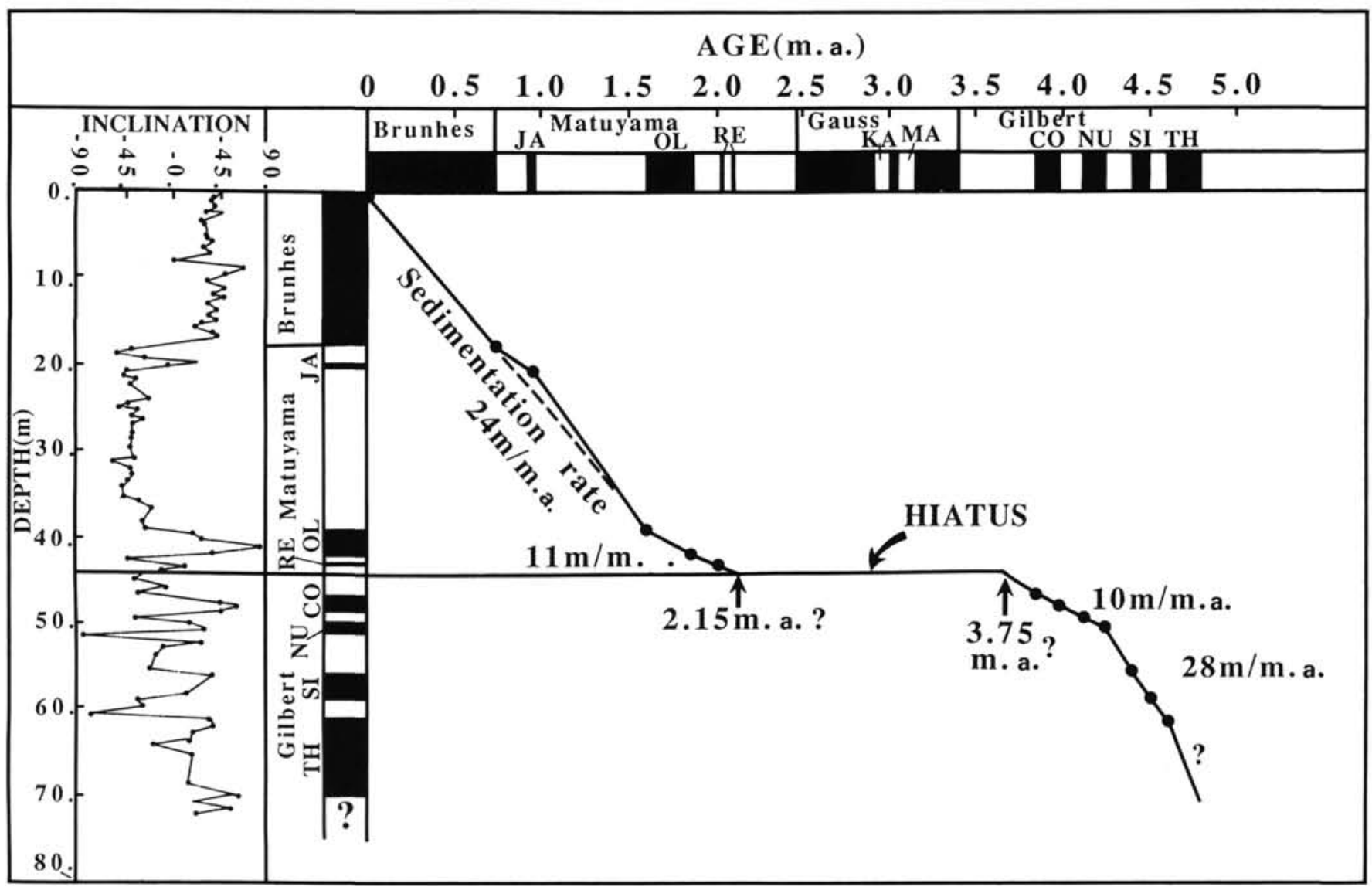

Figure 4. Age vs. depth curve for top $70 \mathrm{~m}$ of Hole 633A based on magnetostratigraphy (Harland et al., 1982). Note the good agreement above Pliocene hiatus with Figure 3 . The presence of several normal events during the Gilbert Chron helps to bring out a break in sedimentation rate by a factor of almost 3 at $\sim 50 \mathrm{mbsf}$ from $10 \mathrm{~m} / \mathrm{m}$.y. to $28 \mathrm{~m} / \mathrm{m}$.y. Hiatus is constrained in age between 2.15 and 3.75 Ma by extrapolating sediment rates just above and below hiatus.

tation ( 23 to $24 \mathrm{~m} / \mathrm{m} . \mathrm{y}$.) during the late to middle Pleistocene is identical to that estimated for the early Pleistocene.

\section{Lower Pleistocene (Fig. 6)}

The lower Pleistocene sequence is constrained within the single nannofossil subzone Gephyrocapsa caribbeanica (CN13b) and the $\mathrm{S}$ and $\mathrm{R}$ zones of the Menardii Complex. It represents the reverse Matuyama Chron, devoid of any normal events between the Jaramillo and Olduvai, and can be dated fairly accurately between 0.9 and $1.6 \mathrm{Ma}$. This time interval has the most turbidite layers of the Pliocene-Pleistocene sequence in Hole 633A. However, these turbidites, some several tens of centimeters thick, constitute no more than $15 \%$ of the total sediment. Less than $10 \%$ of the periplatform ooze is sufficiently indurated to be considered chalk.

Carbonate content in the fine fraction fluctuates between $80 \%$ and $90 \%$. The largest fluctuations occur in the bottom half of Sections 101-633A-4H-4 through 101-633A-4H-6, corresponding approximately to a time interval between 1.3 to 1.6 $\mathrm{Ma}$. For this time, spikes of low carbonate values correspond to short events (usually within a 10 -cm-thick interval). Between 0.9 and $1.3 \mathrm{~m} . y$. ( 21 to $32 \mathrm{mbsf}$ ), the carbonate values remain above $90 \%$, averaging $94 \%$. Quartz-rich intervals correlate with the lowest carbonate values and are generally thinner than similar intervals in the upper Pliocene or the upper to middle Pleistocene.
Aragonite and calcite are the two carbonate phases in the fine fraction. Aragonite content varies from $10 \%$ to $80 \%$ and displays well-defined asymmetric cycles with a sharp increase followed by a gradual decrease, especially between 0.9 and 1.3 $\mathrm{Ma}$. At the bottom of the lower Pleistocene, these aragonite cycles become more irregular. Eleven aragonite cycles (labeled $L$ through $V$ in Fig. 6), as defined in the previous section, can be counted during the $0.7-\mathrm{m}$.y.-long record of this lower Pleistocene section. High aragonite intervals do not always correspond to the highest carbonate values, especially at the bottom of the lower Pleistocene, where the short-term carbonate minima usually occur during the sharp transition from low to high aragonite content or at the aragonite maxima.

The coarse fraction usually makes up less than $20 \%$ of the total sediment. Larger values $(20 \%$ to $60 \%)$ occur only during low-aragonite intervals, where some cementation is observed in the form of overgrowths on foraminifer tests and microclasts. The average sedimentation rate in the lower Pleistocene (23 to $24 \mathrm{~m} / \mathrm{m}$.y.) is identical to the rate for the entire Pleistocene, but it is twice as high as that estimated for the upper Pliocene (see next section).

\section{Upper Pliocene (Fig. 7)}

The 7-m-thick sediment sequence just above the hiatus corresponds to an upper Pliocene interval between 1.6 and $2.15 \mathrm{Ma}$ in age, tentatively correlated with the $\mathrm{Q}$ and $\mathrm{P}$ zones of the Me- 

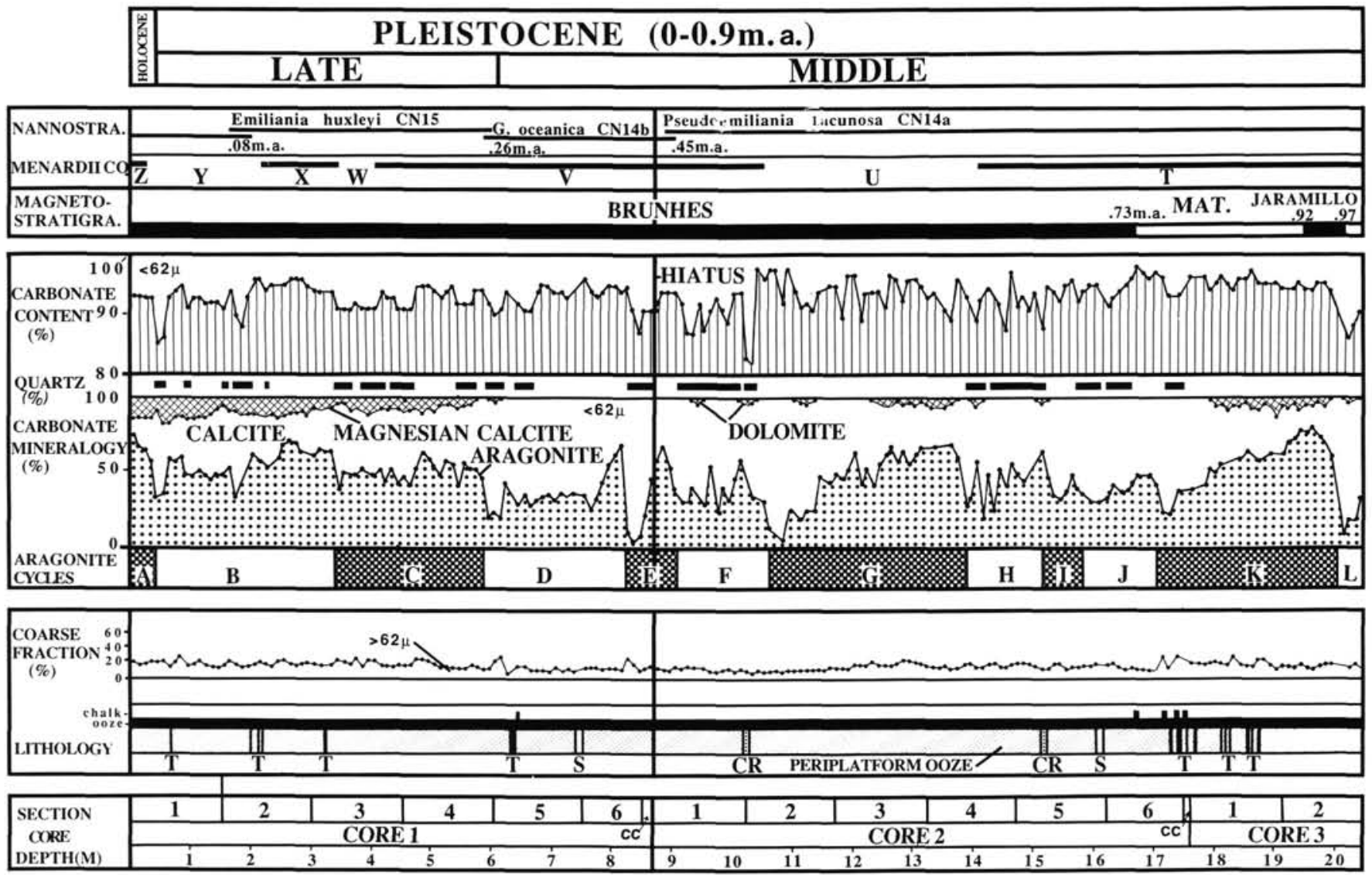

Figure 5. Depth variations of lithology, coarse fraction, carbonate mineralogy, quartz occurrence, and carbonate content within the Holocene through upper and middle Pleistocene (based on magnetostratigraphy), Menardii Complex, and nanno-stratigraphies with identification of 10.5 aragonite interglacial/glacial cycles labeled (from core top) $A$ through $K$. Lithologic abbreviations: $T$, turbidite; $C R$, clay-rich layers; $S$, organic matter or interstitial-water samples.

nardii Complex. It is composed of almost pure periplatform ooze with only a single turbidite layer. Less than $10 \%$ of the sediment is indurated enough to be called a chalk.

Carbonate content in the fine fraction fluctuates between $84 \%$ and $100 \%$, and the intervals of relatively low carbonate content correspond to layers in which quartz is observed on $\mathrm{X}$-ray diffractograms. The range of upper Pliocene carbonate values resembles the Pleistocene carbonate fluctuations and differs from the fairly constant high average lower Pliocene carbonate values described below.

Aragonite and calcite are the two carbonate phases in the fine fraction. Aragonite content varies between $0 \%$ and $50 \%$. Approximately half of the sediment is purely calcitic and therefore only pelagic in origin (Fig. $8 \mathrm{C}$ ). Aragonite-bearing intervals are always relatively high in carbonate, although intervals with high carbonate values do not always correspond to those with aragonite. This is a major difference from what is generally observed in the upper Pleistocene: high carbonate corresponding to high aragonite, and vice versa (Droxler et al., 1983).

The coarse fraction varies from $10 \%$ to $50 \%$. Intervals where coarse-fraction values reach $20 \%$ or more are mainly composed of agglomerates, microclasts, and foraminifer tests with calcite overgrowths. These intervals correspond to low-carbonate and low-aragonite or aragonite-free intervals. The average sedimentation rate ( 11 to $12 \mathrm{~m} / \mathrm{m}$.y.) during the late Pliocene, calculated using both nannofossil biostratigraphy and magnetostratigraphy (Figs. 3 and 4), is one of the lowest in the Pliocene-Pleistocene sequence. This interval of low sedimentation rate also cor- responds to intermittent occurrence of aragonite and long sections of pure calcite.

\section{Lower Pliocene (Fig. 7)}

Sediment in the lower Pliocene interval between 3.75 and $4.45 \mathrm{Ma}$ is a periplatform ooze/chalk devoid of turbidite layers. Approximately $40 \%$ of the ooze is sufficiently indurated to be considered a chalk. Carbonate content of the fine fraction is very high, generally greater than above the hiatus (upper Pliocene-Quaternary), and remains fairly constant between $93 \%$ and $99 \%$. Absence of quartz on the X-ray diffraction diagrams demonstrates that the terrigenous input during the early Pliocene is either nonexistent or too small to be detected by our analytical methods. Three carbonate phases are present in the fine fraction: aragonite, calcite, and dolomite. Aragonite and calcite are the two major components, with dolomite quantitatively of secondary importance. In the bottom half of Core 101-633A-6H, aragonite content is as high as in Pleistocene interglacial maxima intervals from piston cores (Droxler et al., 1983; Boardman et al., 1986) and fluctuates between $50 \%$ and $70 \%$ (average $60 \%$ ). Aragonite content fluctuates between $30 \%$ and $60 \%$ (average $45 \%$ ) in the upper half of Core 101-633A-6H and varies between $0 \%$ and $40 \%$ (average 20\%) in Sections 101-633A-5H-6 and $101-633 \mathrm{~A}-5 \mathrm{H}-7$. In summary, the aragonite content of the lower Pliocene section decreases incrementally upward. It is significant that high sedimentation rates $(28 \mathrm{~m} / \mathrm{m}$.y.) prior to 4.25 Ma (Nunivak event, Fig. 4) correspond to an interval of high, fairly constant aragonite content, whereas low sedimentation 


\begin{tabular}{|l|c|}
\hline \multicolumn{2}{|c|}{ PLEISTOCENE $(0.9-1.6 \mathrm{~m} . \mathrm{y})}$. \\
\hline MI. & EARLY \\
\hline
\end{tabular}

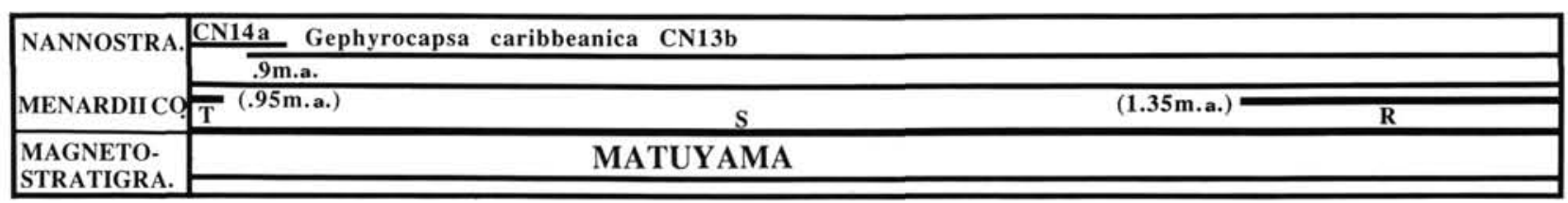
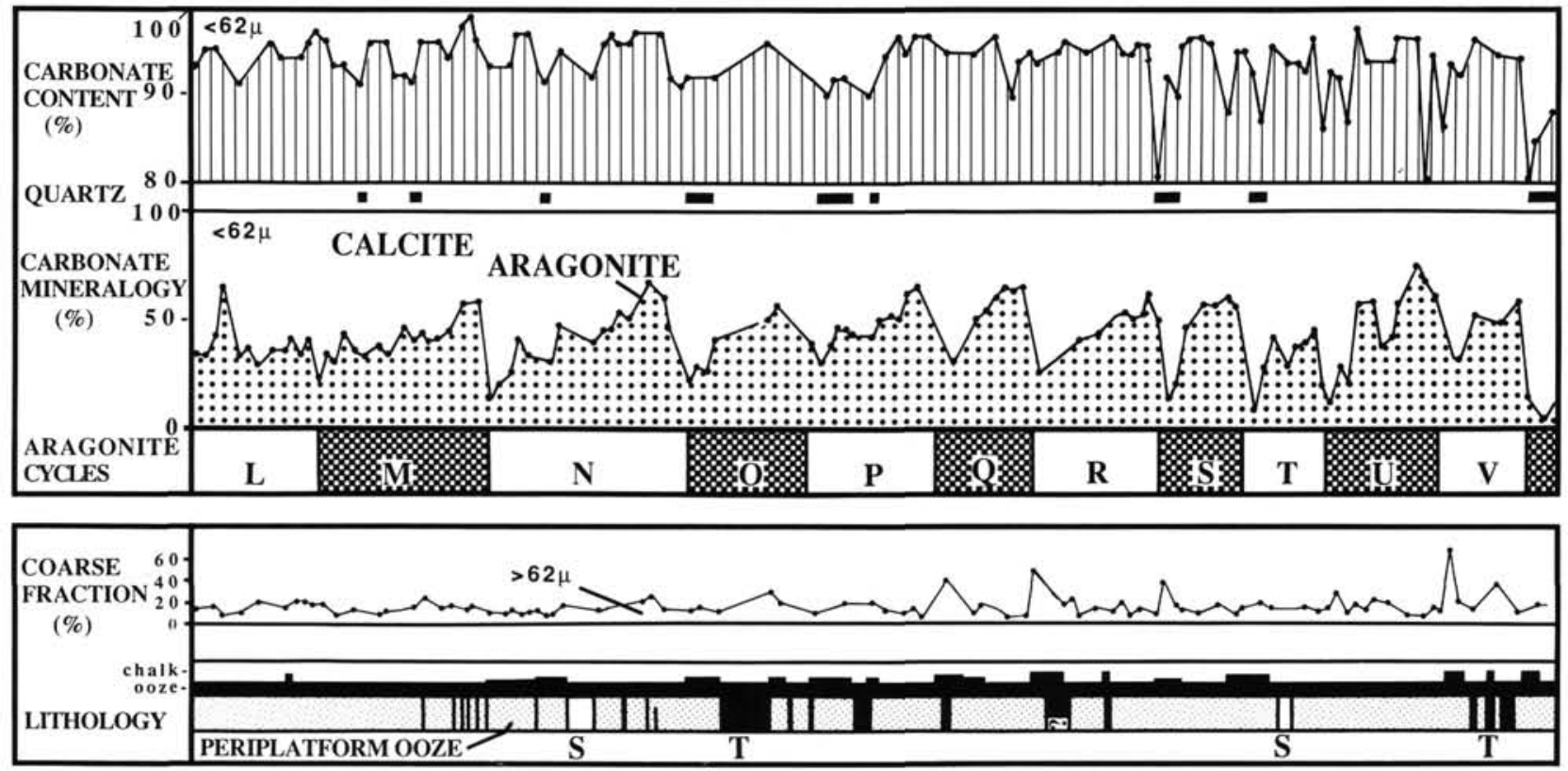

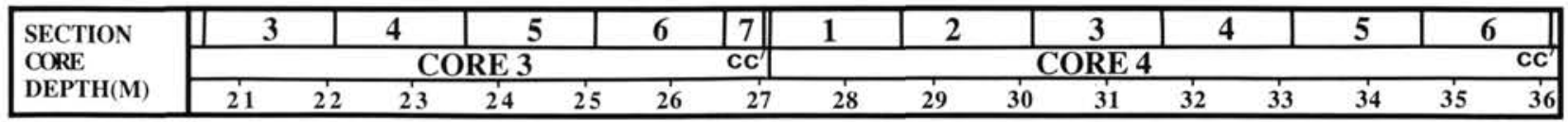

Figure 6. Depth variations of lithology, coarse fraction, carbonate mineralogy, quartz occurrence, and carbonate content within the lower Pleistocene (based on magnetostratigraphy), Menardii Complex, and nanno-stratigraphies with identification of 11 aragonite interglacial/ glacial cycles labeled (from core top) $L$ through $V$. (See Figure 5 caption for lithologic abbreviations.)

rates $(10 \mathrm{~m} / \mathrm{m} . \mathrm{y}$.$) between 3.75$ and $4.25 \mathrm{Ma}$ coincide with a period of incremental drop of aragonite content in samples from the $7 \mathrm{~m}$ of sediment just below the hiatus.

Dolomite is always $<8 \%$ throughout this interval, with the exception of Section 101-633A-5H-6 (immediately below the hiatus), where dolomite constitutes as much as $25 \%$ of the total carbonate. Observations by SEM show that the sediment is composed mainly of easily identifiable coccolith plates, as well as recrystallized(?) material with some needlelike individual particles that are interpreted as being aragonitic on the basis of $\mathrm{X}$-ray-diffraction analyses. Dolomite appears as clear rhombs 10 to $20 \mu \mathrm{m}$ in size within the fine matrix, and is therefore interpreted (Mullins et al., 1985) to be authigenic and diagenetically produced (Fig. 8, A and B). The dolomite precursor could have been some bank-derived diagenetically metastable magnesian calcite, which usually occurs intermittently in the upper and middle Pleistocene. However, it is not clear that dolomite is formed by recrystallization of magnesian calcite, since both dolomite and magnesian calcite are commonly absent simultaneously in the Pliocene-Pleistocene periplatform ooze.

The sudden decrease of the coarse fraction in the middle of Section 101-633A-6H-3 from an average of $50 \%$ to less than $20 \%$ is evidently the result of diagenetic processes. The coarse fraction in the bottom half of Core 101-633A-6H is composed primarily of agglomerates and cemented clasts, and not only of foraminifer tests as it is in the case in the top half of Core 101$633 \mathrm{~A}-6 \mathrm{H}$, where the coarse fraction is $<20 \%$ of the total sediment.

\section{Overall Pliocene-Pleistocene Trends in Carbonate Content, Carbonate Mineralogy, and Coarse-Fraction Proportions}

Average values of carbonate content are close to $100 \%$ and mostly constant in Hole $633 \mathrm{~A}$ in the lower Pliocene (43.75 to $55.00 \mathrm{mbsf}$ ) and in the upper half of the lower Pleistocene. These values are somewhat lower and characterized by rapid excursions to relatively low values (down to $77 \%$ ) in the rest of the Pleistocene and the upper Pliocene. It is therefore significant that the lower Pliocene interval represents a time during which terrigenous input was at its minimum or was nonexistent.

Results of the carbonate mineralogical studies show irregular aragonite fluctuations and indistinct aragonite cycles in the upper Pliocene and well-developed and clearly asymmetric aragonite cycles throughout the Quaternary. Surprisingly, the highest and most constant aragonite values occur in the lower Pliocene; these values decrease by several steps within just a few meters below the Pliocene hiatus. 


\section{PLIOCENE (1.6-2.15 m.a.) LATE}

\begin{tabular}{|c|c|}
\hline \multirow{3}{*}{$\begin{array}{l}\text { NANNOSTRA. } \\
\text { MENARDII CO. }\end{array}$} & CN13b E. annula CN13a Calcidiscus macintyrei CN12d \\
\hline & \begin{tabular}{|lll}
$1.6 \mathrm{~m} . \mathrm{a}$. & $1.9 \mathrm{~m} . \mathrm{a}$. & $2.2 \mathrm{~m} . \mathrm{a} . ?$ \\
\end{tabular} \\
\hline & $\bar{R}^{(1.65 \mathrm{~m} \text {.a. })}$ \\
\hline $\begin{array}{l}\text { MAGNETO- } \\
\text { STRATIGRA. }\end{array}$ & MAT. $1.67 \mathrm{~m}$. a.OLDUVAI $1.87 \mathrm{~m}$.a. REUNION $2.0 \mathrm{~m}$.a. \\
\hline
\end{tabular}
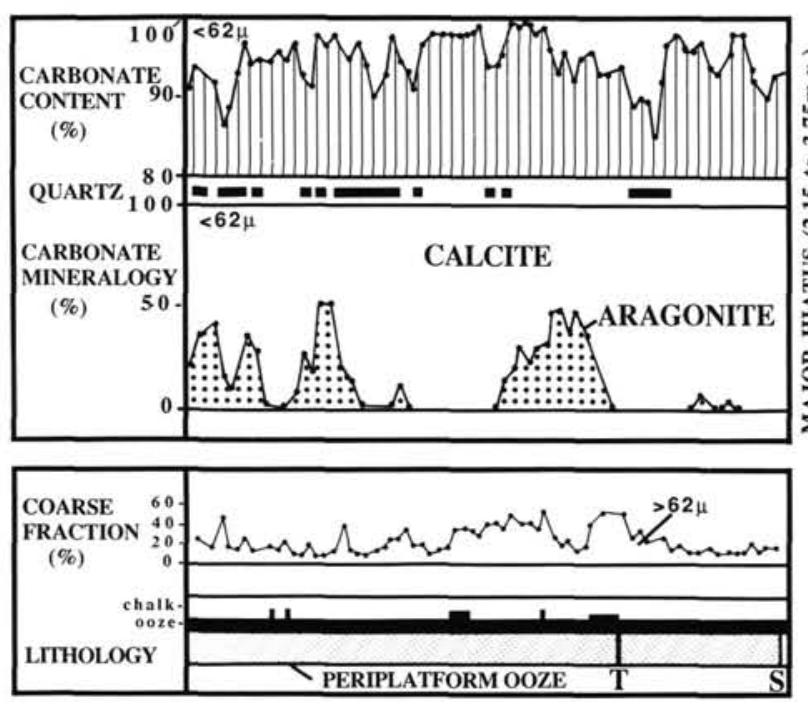

\begin{tabular}{|c|c|c|c|c|c|c|c|}
\hline \multirow{3}{*}{$\begin{array}{l}\text { SECTION } \\
\text { CORE } \\
\text { DEPTH(M) }\end{array}$} & 1 & 2 & & 3 & & & 5 \\
\hline & \multicolumn{7}{|c|}{ CORE 5} \\
\hline & 37 & 38 & 39 & 40 & 41 & 42 & 43 \\
\hline
\end{tabular}

\begin{tabular}{|c|}
\hline PLIOCENE (3.75-4.4 m.a.) \\
\hline EARLY \\
\hline
\end{tabular}
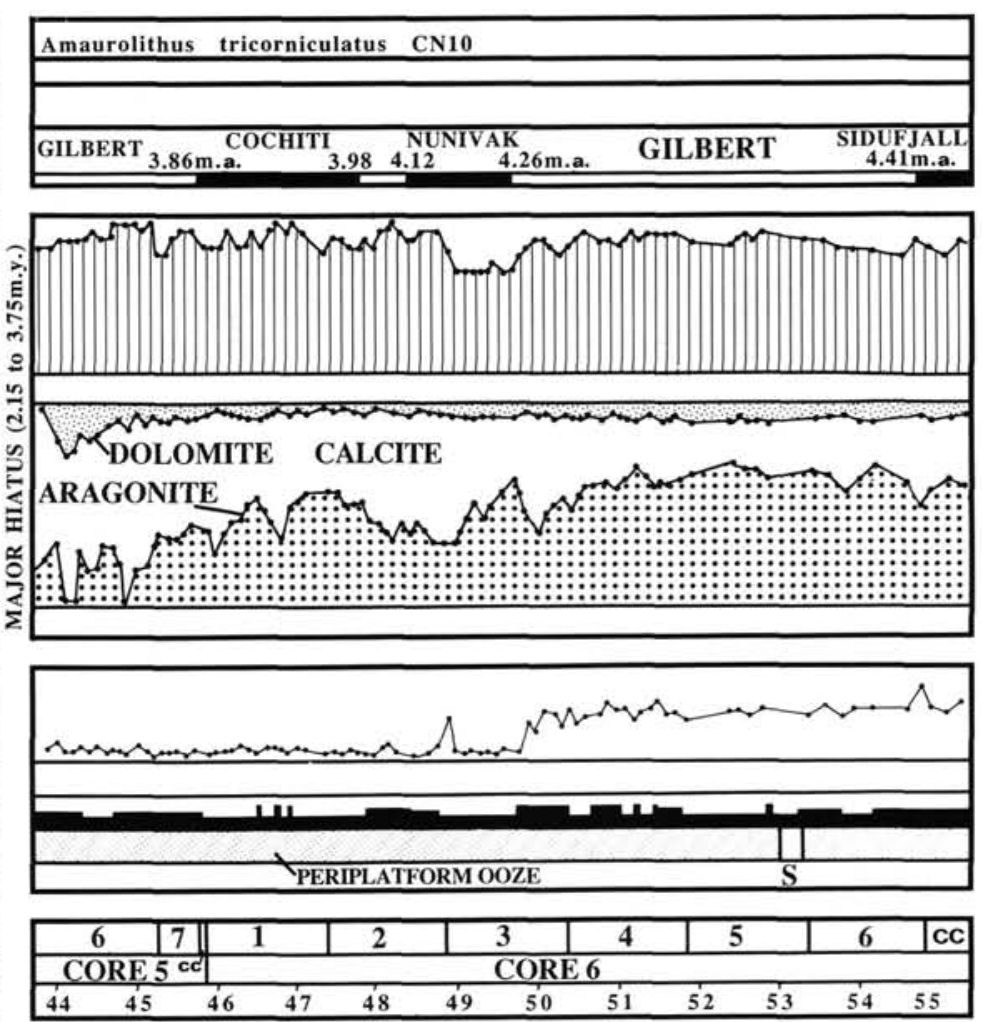

Figure 7. Depth variations of lithology, coarse fraction, carbonate mineralogy, quartz occurrence, and carbonate content within the Pliocene (based on magnetostratigraphy), Menardii Complex, and nanno-stratigraphies. (See Figure 5 caption for lithologic abbreviations.)

Magnesian calcite as a secondary mineral reaches maximum values at the top of Hole $633 \mathrm{~A}$, then decreases downhole and disappears at 6 mbsf. It reappears only in two well-developed aragonite-rich intervals. Dolomite as a secondary mineral is also ubiquitous in the lower Pliocene and appears only as traces in association with clay-rich layers in the Pleistocene. The highest proportions of the coarse-sized fraction $(>20 \%)$ correspond to evidences of partial cementation in microclasts, and calcite overgrowths in foraminiferal tests occur in the upper Pliocene and the lower half of the lower Pliocene, where aragonite values are usually constant and high $(\sim 60 \%)$.

\section{Pliocene-Pleistocene Oxygen-Isotope Record and Its Correlation with Variations in Aragonite Content}

We have produced an almost complete oxygen-isotope planktonic record using Globigerinoides sacculifera and Globigerinoides rubra (pink) in the top $47 \mathrm{~m}$ of Hole 633A. This record includes the past $2.15 \mathrm{~m} . \mathrm{y}$. above the Pliocene hiatus at 43.75 mbsf, and a time interval between 3.75 and $3.9 \mathrm{Ma}$ in the $3.5 \mathrm{~m}$ of periplatform ooze just below the hiatus. The results are shown in Figure 9 (Pleistocene), Figure 10 (Pliocene), and the Appendix.

\section{Oxygen-Isotope Planktonic Record (Figs. 9 and 10)}

The Pleistocene oxygen-isotope record (top $36.50 \mathrm{~m}$ of Hole 633A) clearly displays its two commonly observed modes: lowfrequency/high-amplitude cycles in the upper and middle Pleistocene (Brunhes Chron and Matuyama Chron to Jaramillo Event, $0.97 \mathrm{Ma}$ to present) and high-frequency/low-amplitude cycles in the lower Pleistocene (in the Matuyama Chron from the top of the Olduvai Event to the bottom of the Jaramillo Event, 1.67 to $0.97 \mathrm{Ma}$ ). These two modes were observed by Shackleton and Opdyke (1976) in the Pacific Ocean (core V28239), by Prell (1982) in the Caribbean Sea (DSDP Hole 502B), and by Shackleton et al. (1984) in the North Atlantic Ocean (DSDP Hole 552A). In Hole 633A, the maximum glacial/interglacial amplitudes in the lower Pleistocene mode fall, with a few exceptions, within a range of values between $0.5 \%$ and $-1.5 \%$, whereas in the middle/upper Pleistocene mode, values of maximum amplitudes range between $1.3 \% 0$ and $-2.0 \%$.

Identification of the successive oxygen-isotope stages for the late Pleistocene is not straightforward. However, using the biostratigraphic markers based on nannofossils, the Menardii Complex zones, and the magnetic reversals, we tentatively identify the 23 oxygen-isotope stages defined by Shackleton and Opdyke (1976) in piston core V28-239. In our interpretation of the oxygen-isotope record of Hole 633A, as in piston core V28-239, the Brunhes/Matuyama reversal lies on the stage 20/21 boundary, and the top of the Jaramillo Event falls in stage 23. As globally recorded for the late and middle Pleistocene (Thierstein et al., 1977), the last-occurrence datum (LAD) of Pseudoemiliania lacunosa is located in stage 12, the first-occurrence datum (FAD) of Emiliania huxleyi in stage 8, and the beginning of the E. huxleyi acme zone at the end of stage 5. In addition, as in core V16-205 from the tropical Atlantic Ocean (Van Donk, 1976), the Z Zone of the Menardii Complex corresponds to the Holocene or stage 1; the $\mathrm{Y}$ and $\mathrm{X}$ zones roughly to stages 2 to 4 and stage 5, respectively; the W Zone to stage 6; the V Zone from stages 7 to 13 ; the U Zone from stages 14 to 15 ; and, finally, the T zone from stages 16 to 23 . 


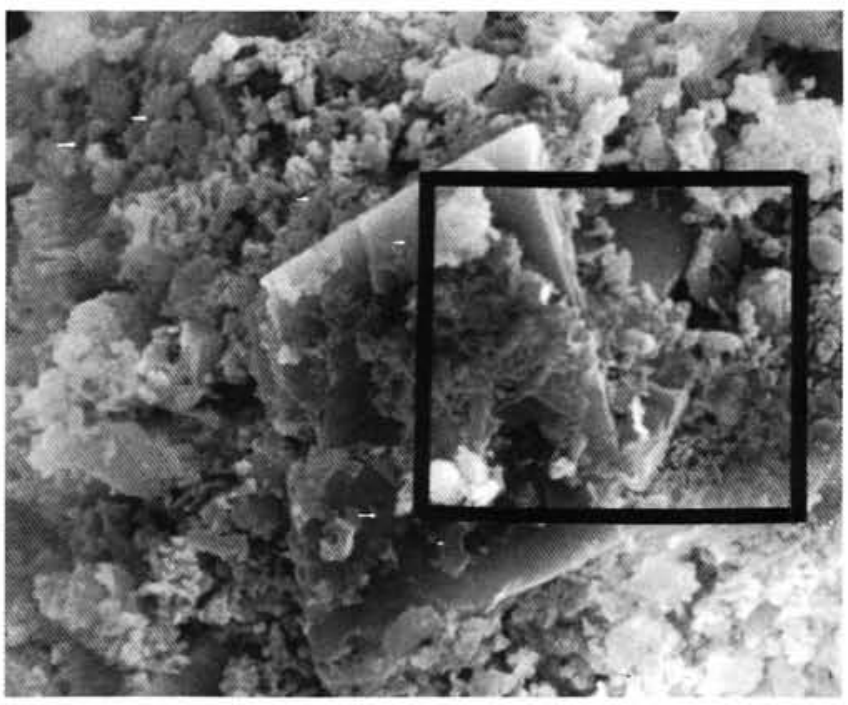

A

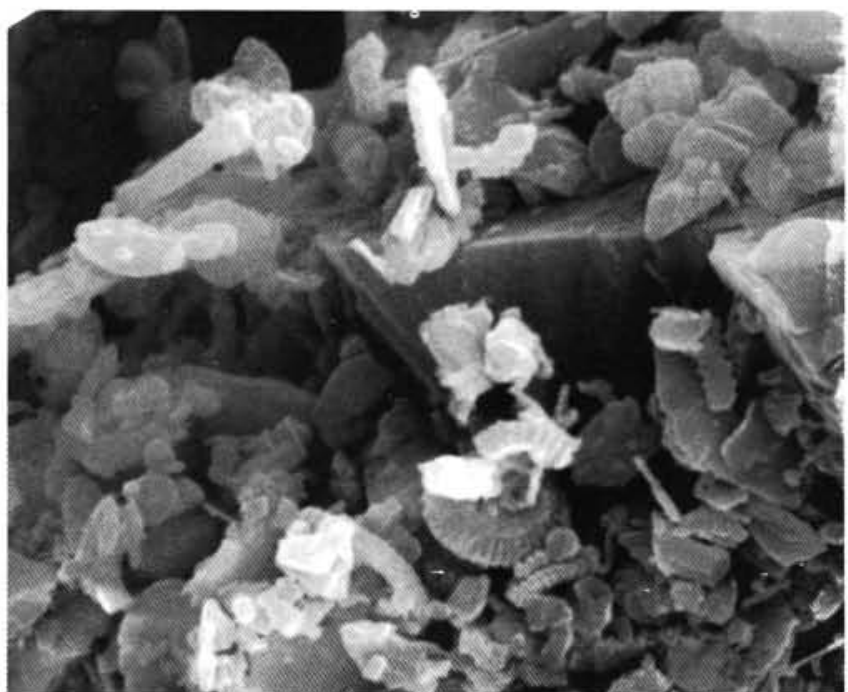

B

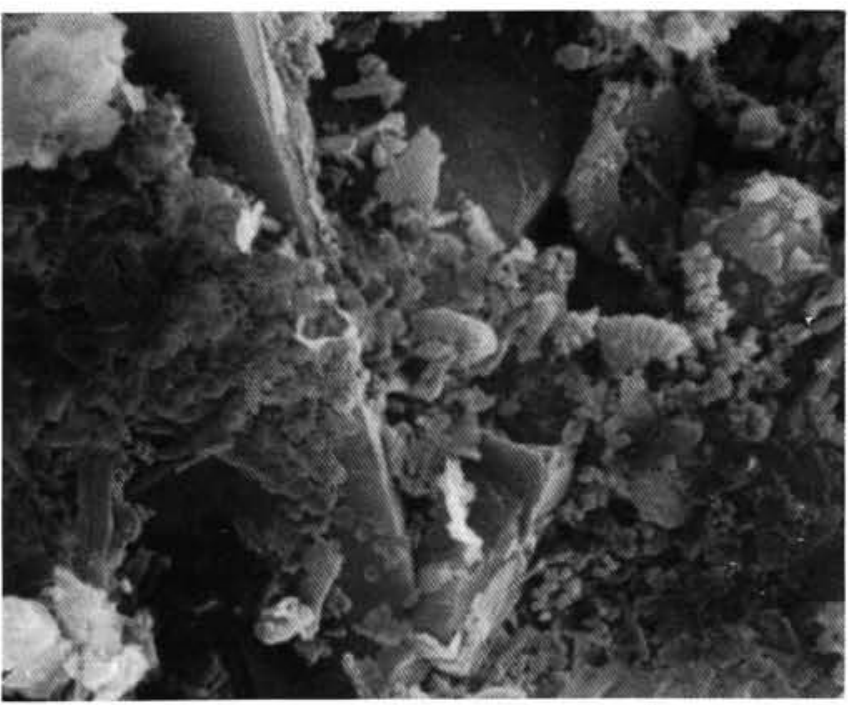

$A^{\prime}$

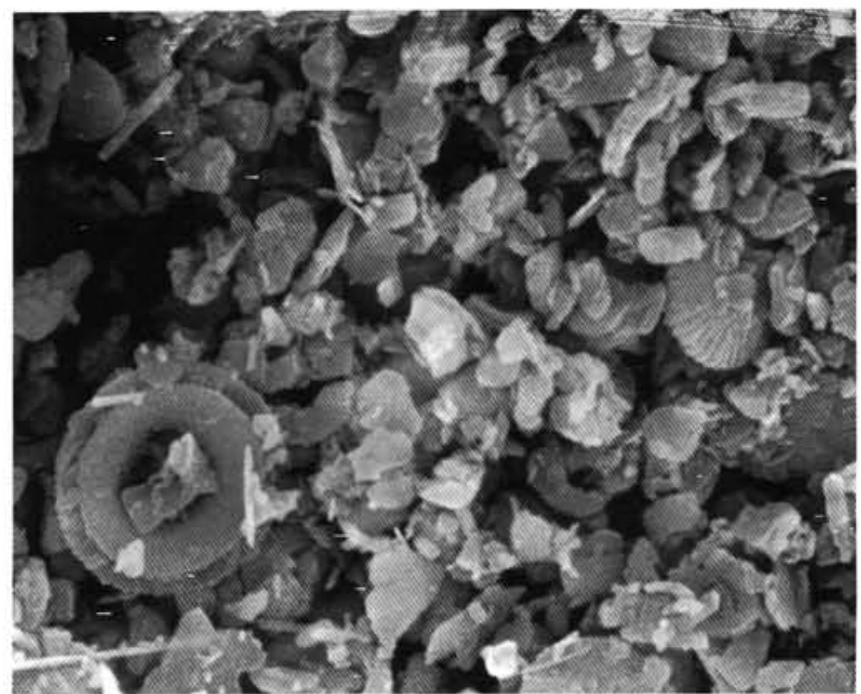

C

Figure 8. SEM photomicrographs of Pliocene periplatform carbonate ooze. A. Sample 101-633A-6H-6, $85-87 \mathrm{~cm}$; dolomite rhomb growing within a matrix of coccolith plates and recrystallized(?) aragonite particles, some still appearing as needles; bar $=5 \mu \mathrm{m} ; \times 3000$. $\mathrm{A}^{\prime}$. Detail of micrograph A; $\mathrm{bar}=2.5 \mu \mathrm{m} ; \times 7000$. B. Sample 101-633A-5-6, 34-35 cm; dolomite rhomb growing within a matrix of pure calcitic particles, mainly coccolith plates and undifferentiated grains; bar $=2.5 \mu \mathrm{m} ; \times 5500$. C. Sample 101-633A-5-5, 134-135 cm; pure calcitic ooze, mainly coccolith plates and some undifferentiated grains; bar $=5 \mu \mathrm{m} ; \times 4500$.

As in other records, glacial stages 12,16 , and 22 in Hole 633A (middle Pleistocene) are among the heaviest oxygen-isotope values, and interglacial stages 17,19 , and 21 are the least developed. Glacial stage 14 , usually characterized by relatively light oxygen-isotope values, shows oxygen values in Hole 633A as heavy as those during stage 12 . The beginning of interglacial stage 5 (5e) seems to be partly missing; a small hiatus could be induced by the occurrence of a turbidite layer at that level $(3.20$ to $3.30 \mathrm{mbsf}$ ). In addition, the glacial/interglacial record loses its resolution between stages 11 and 12 , which coincides with the transition between Cores 101-633-1 H and 101-633-2H and therefore could be related to drilling disturbances. The general pattern of the oxygen-isotope record in Hole 633A in the upper and middle Pleistocene is somewhat peculiar, as some of the interglacial stages are extended (i.e., stages 15 and 23). Sedimen- tation rates in the Bahamas are reported to be much higher for the late Pleistocene than during glacial stages by a factor of 4 to 8 (Droxler et al., 1983; Boardman and Neumann, 1984; Droxler and Schlager, 1985a; Reymer et al., this volume). This may be because of preferential highstand input of bank-derived carbonates and possibly because of preferential interglacial aragonite preservation. This contrasts with the open ocean, where the glacial record may be extended, owing to preferential terrigenous input during a lowstand interval.

The difficulty in identifying clear glacial/interglacial stages in the lower Pleistocene can be explained by their higher frequency and lower amplitude. In Hole 633A, upper Pliocene oxygen-isotope values are similar to those from the lower Pleistocene. This differs from the oxygen-isotope record of DSDP Hole 552A, where glacial/interglacial cycles in the upper Plio- 


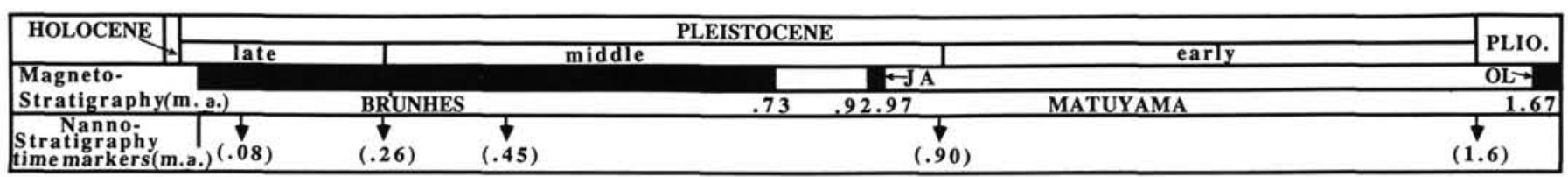

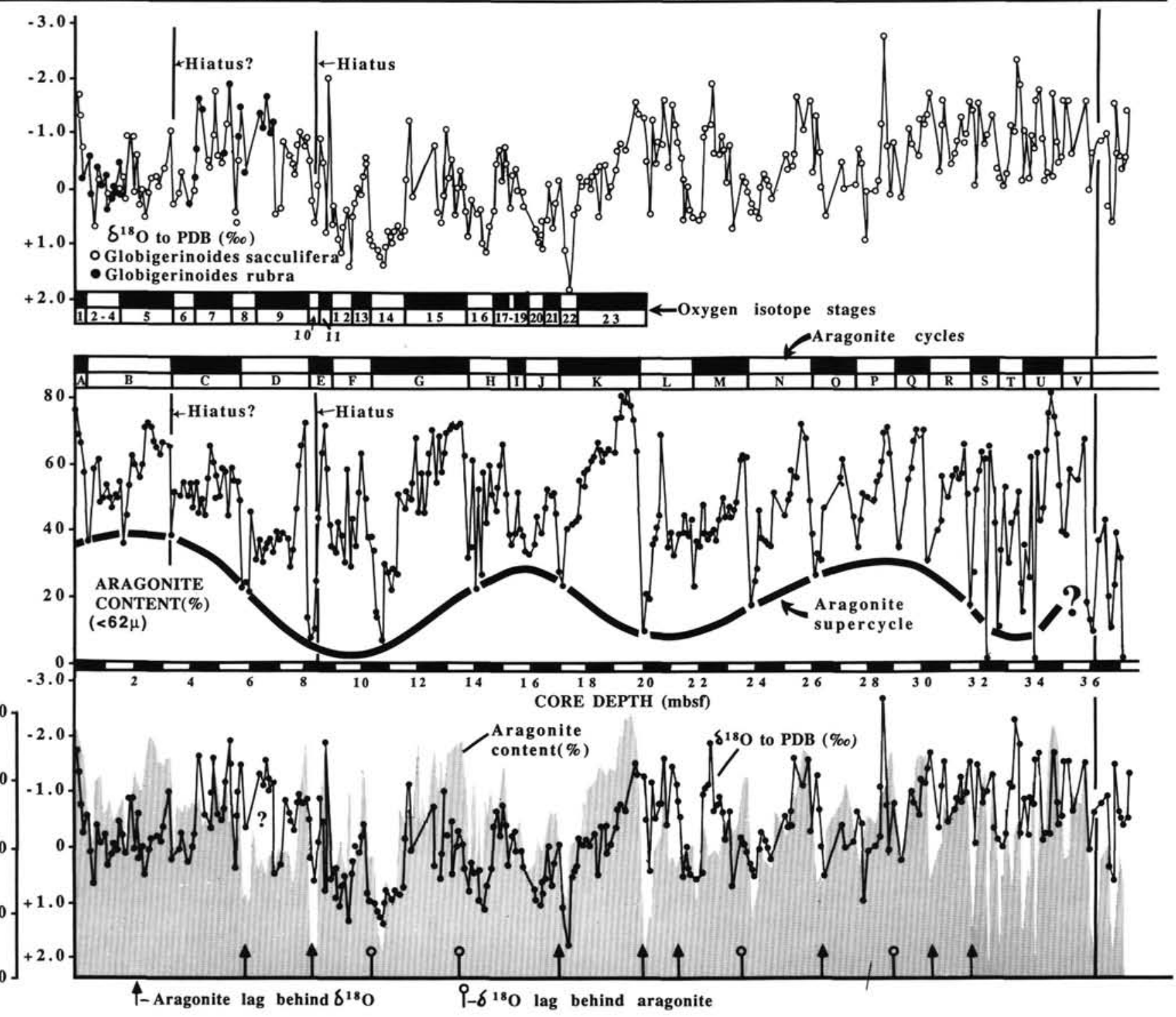

Figure 9. Quaternary oxygen-isotope planktonic record (upper diagram) and aragonite cycles and supercycles in fine-sediment fraction ( $<62 \mu \mathrm{m})$ (middle diagram). Records are superimposed for easier visual comparison (lower diagram) and placed on a time scale based on magneto- and nannostratigraphic time markers. Twenty-three oxygen-isotope stages are identified within the first 1 m.y. (Holocene, upper and middle Pleistocene). Twenty-one and one-half aragonite cycles (each cycle including one interglacial and one glacial interval) are identified (from core top down) and labeled $A$ through $V$. (See text for general description and discussion.)

cene are more upper Pleistocene-like with generally intermediate amplitudes (Shackleton et al., 1984).

The short $\delta^{18} \mathrm{O}$ record in the lower Pliocene ( 3.9 to $3.75 \mathrm{Ma}$ ) just below the hiatus first shows a steep decrease of oxygen values by $2.2 \%$, followed by a plateau with an average value of $0 \%$. The timing $(\sim 3.8 \mathrm{Ma})$ of this climatic deterioration fits well with the interpretation that the early Pliocene was a prolonged interval of warm interglacial conditions starting around $5 \mathrm{Ma}$, which ended at 4.1 Ma with a sharp climatic cooling (Hodell and Kennett, 1986). The sea-level curve of Haq et al. (1987) also shows a sharp drop between 4.0 and $3.8 \mathrm{Ma}$.

\section{Correlations Between Aragonite Cycles and Oxygen-Isotope Record}

\section{Quaternary (Holocene-Pleistocene, 0-1.6 Ma) (Fig. 9)}

In this paper we visually compare the oxygen-isotope record and the aragonite cycles. In Figure 9, the oxygen-isotope record and the aragonite cycles are displayed both separately and superimposed to facilitate the comparison.

Excellent correlations between the $\delta^{18} \mathrm{O}$ record and aragonite cycles in the upper Pleistocene and part of the middle Pleistocene were found by Droxler et al. (1983). Their study examined 


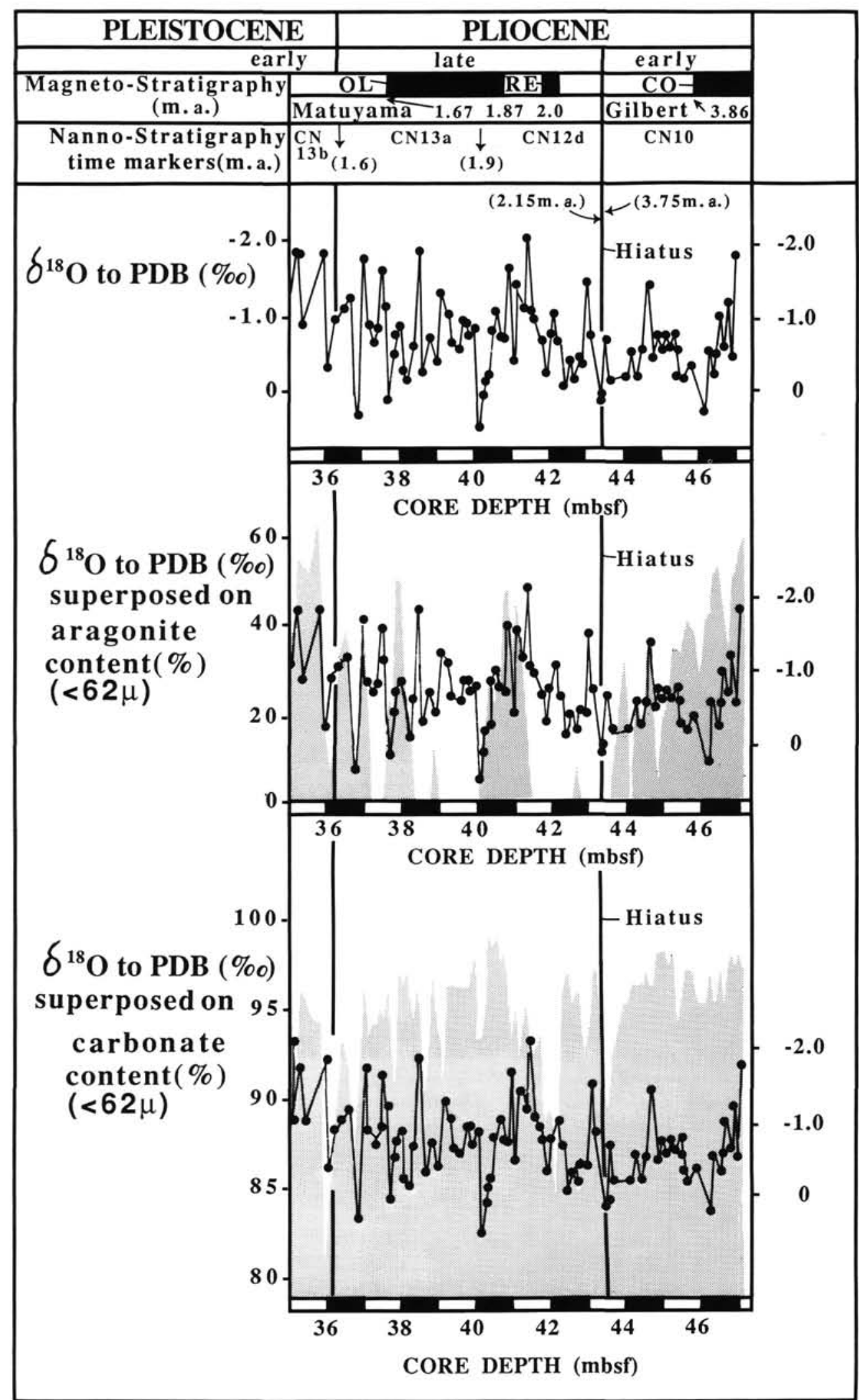

Figure 10. Pliocene oxygen-isotope planktonic record (upper diagram), superimposed on aragonite variations (middle diagram) and on carbonate variations (lower diagram). Note that in the upper Pliocene a good correlation exists between the oxygen-isotope record and carbonate cycles, whereas irregular low values of aragonite, or intervals characterized by absence of aragonite, show no clear relationship with either the oxygen-isotope record or the carbonate cycles. In the lower Pliocene the aragonite decrease corresponds to a distinct increase of oxygen-isotope values, and carbonate values remain high and constant. (See text for general description and discussion.) 
piston core GS-7705-34, taken in Tongue of the Ocean $(1935 \mathrm{~m}$ water depth) and containing a record of the past 0.35 m.y. (similar to Hole 633A). Kiefer (1983) and Boardman et al. (1986) report similar results from piston core $\mathrm{CH}-8201-07$, Northwest Providence Channel (675 m water depth), which contains a record of the past 0.50 m.y. (Kiefer, 1983; Boardman et al., 1986). More recent research on periplatform ooze from the Nicaragua Rise (Caribbean Sea) and from the Maldives (Indian Ocean) has confirmed the correlation between the aragonite cycle and oxygen-isotope record during the past 0.35 m.y. (Droxler, 1986a).

The general visual correlation between aragonite content and $\delta^{18} \mathrm{O}$ in the much longer record of Hole $633 \mathrm{~A}$ is quite good, in spite of several mismatches that might be significant in interpreting the origin of the aragonite cycles. In Core 101-633A-1 H (0-8.7 mbsf), covering the Holocene, upper Pleistocene, and part of the middle Pleistocene $(0-0.45 \mathrm{Ma})$, the correlations between $\delta^{18} \mathrm{O}$ and the aragonite cycles are not as clear as in the other records from piston cores (Droxler et al., 1983; Boardman et al., 1986; Droxler, 1986a). A possible hiatus at the beginning of isotope stage 5 (5e), equivalent to aragonite cycle B, as well as in isotope stage 11, equivalent to aragonite cycle $\mathrm{E}$ can partially explain some of the discrepancies between $\delta^{18} \mathrm{O}$ and the aragonite cycles (although the latter example may be related to drilling disturbances at the transition between Cores 101-633A-1 $\mathrm{H}$ and 101-633A-2H). In addition, long and frustrating analytical problems arose during oxygen-isotope analysis of samples from the top $7 \mathrm{~m}$ of Core 101-633A-1H; duplicate and even triplicate analyses (some based on Globigerinoides rubra) had to be run to resolve some of the discrepancies.

Mismatches between the oxygen-isotope record and the aragonite cycles seem to occur at several glacial-to-interglacial transitions, where the aragonite increase lags behind the $\delta^{18} \mathrm{O}$ depletion. The most obvious cases are boundaries 10 to 9 (E/D), 12 to $11(\mathrm{~F} / \mathrm{E}), 22$ to $21(\mathrm{~K} / \mathrm{G})$, and 24 to $23(\mathrm{~L} / \mathrm{K})$ in the middle Pleistocene, and several cases in the lower Pleistocene, at boundaries $\mathrm{M} / \mathrm{L}, \mathrm{O} / \mathrm{N}, \mathrm{R} / \mathrm{Q}$, and $\mathrm{S} / \mathrm{R}$. In a few instances, the opposite seems to occur; the aragonite increase precedes the $\delta^{18} \mathrm{O}$ depletion at the boundaries $\mathrm{H} / \mathrm{G}, \mathrm{N} / \mathrm{M}$, and $\mathrm{Q} / \mathrm{P}$. More detailed studies based on closer sampling (3- to 5-cm-spaced samples) of these particular glacial-to-interglacial boundaries will be necessary in order to quantify and to better understand the lags between the aragonite increase and the $\delta^{18} \mathrm{O}$ depletion at the glacial-to-interglacial transitions.

\section{Pliocene (Fig. 10)}

The correlation between the $\delta^{18} \mathrm{O}$ record and the aragonite curve is more tenuous in the upper Pliocene (1.6 to $2.15 \mathrm{Ma}$ ) than in the Quaternary ( 0 to $1.6 \mathrm{Ma}$ ). Although the Pliocene oxygen-isotope cycles are almost identical to the lower Pleistocene cycles in terms of amplitude and frequency, aragonite is not always present, and the correspondence between $\delta^{18} \mathrm{O}$ and the aragonite curve is not always straightforward. Interglacial (light-oxygen-isotope) intervals may correspond to aragonite-rich intervals but can in other cases coincide with pure calcitic ooze. Although the glacial/interglacial mode during the late Pliocene is well established after the onset of major glaciations in the North Atlantic Ocean 2.4 m.y. ago in DSDP Hole 552A (Shackleton et al., 1984), as well as in DSDP Hole 502B (Prell, 1982) and now in Hole 633A, occurrence of climatically induced aragonite cycles remains unclear in the upper Pliocene. The climatically induced aragonite cycles start at the Pliocene-Pleistocene transition, 1.6 m.y. ago at 36.5 mbsf in Hole $633 \mathrm{~A}$, and are fully developed, displaying a good correlation with the $\delta^{18} \mathrm{O}$ planktonic record throughout the Quaternary.

The short lower Pliocene $\delta^{18} \mathrm{O}$ record and the aragonite curve in the $3 \mathrm{~m}$ of sediment just below the Pliocene hiatus are significant. Comparison of the records shows that the $\delta^{18} \mathrm{O}$ increase of
$2.2 \%$ at around $3.8 \mathrm{Ma}$, which might represent the well-established climatic deterioration between 3.9 and $3.75 \mathrm{Ma}$ (Hodell and Kennett, 1986; Haq et al., 1987), parallels a fairly sharp decrease of aragonite content (from $55 \%$ to $25 \%$ ).

\section{DISCUSSION}

The detailed study of the top $55 \mathrm{~m}$ in Hole $633 \mathrm{~A}$ has extended the aragonite record much farther back in time than we thought possible before Leg 101 . Hole 633A contains a nearly complete high-resolution Quaternary record, and in spite of a 1.6-m.y.-long hiatus, its partial Pliocene record bears important findings.

\section{Quaternary Aragonite Cycles}

Asymmetric aragonite cycles are developed throughout the entire Quaternary sequence and are well correlated with a planktonic oxygen-isotope record. The aragonite record, as is already well established for the oxygen-isotope record, displays high-frequency cycles (one cycle every $50,000 \mathrm{yr}, 11$ cycles, L through V, in $0.6 \mathrm{~m} . \mathrm{y}$.$) , in the lower Pleistocene whereas in the middle and$ upper Pleistocene, relatively low frequency cycles occur (one cycle every $100,000 \mathrm{yr}, 10.5$ cycles, A to K, in 1.0 m.y.). Aragonite maxima remain fairly constant throughout the Pleistocene (averaging $\sim 40 \%$ ). The amplitude of the sharp aragonite increase at each cycle boundary can be as high as $75 \%$ and as low as $25 \%$. It is significant, however, that the large-amplitude variations of the aragonite cycles do not occur at random but seem to be organized within a roughly $0.5-\mathrm{m}$.y. supercycle. This supercycle includes three intervals characterized by extremely low aragonite values at (1) 0.3 to $0.5 \mathrm{Ma}$, within the mid-Brunhes centered at the LAD of Pseudoemiliania lacunosa; (2) 0.9 to 1.0 $\mathrm{Ma}$, within the Jaramillo Event; and (3) 1.4 to $1.5 \mathrm{Ma}$ (just above the Pliocene/Pleistocene contact). One-half of the last 0.5 -m.y.-long aragonite supercycle has been observed in at least four cores, collected in water depths ranging between 1200 and $2000 \mathrm{~m}$, from two Bahamian basins. Figure 11A shows a plot of average aragonite values for the last four glacial intervals, corresponding to isotope stages 2 through $4,6,8$, and 10 , during the last $0.35 \mathrm{~m} . \mathrm{y}$. in two piston cores from Tongue of the Ocean, P-7102-14 (Droxler, 1984) and GS-7705-34 (Droxler et al., 1983), and in ODP Holes 632A (Reymer et al., this volume) and 633A (this chapter). In the four cores, aragonite values are minimum during isotope glacial stage 10 and maximum during isotope stage 6 .

The aragonite supercycles look suspiciously similar to lowfrequency carbonate Quaternary cycles (wavelength on the order of 0.5 m.y.), observed in the equatorial Pacific Ocean by Hays et al. (1969), Saito et al. (1975), and Adelseck (1977); in the north-central Pacific Ocean (Vincent, 1985); in the equatorial Indian Ocean (Peterson and Prell, 1985); and in the North Atlantic (Crowley, 1985). The three intervals of lowest aragonite values during the Quaternary in Hole 633A correspond chronologically quite well to three intervals of very low carbonate values defined in three Pacific cores (RC-11-209, V-24-58, and RC-12-66): (1) the middle Brunhes minimum (B5 to B11), (2) the Jaramillo minimum (M1 to M7), and (3) the middle Matuyama minimum (M11 to M13) (Hays et al., 1969; Saito et al., 1975; Vincent, 1985). The last middle Brunhes carbonate minimum has been shown to occur worldwide and has been interpreted to be directly caused by a global increase of carbonate dissolution, which was observed in the Pacific Ocean by Adelseck (1977), in the Indian Ocean by Peterson and Prell (1985), and in the Atlantic Ocean by Crowley (1985).

Because the timing of the $0.5-\mathrm{m}$.y.-long Quaternary carbonate dissolution cycles is so close to the timing of the aragonite supercycles in Hole 633A, we are tempted to interpret by analogy the aragonite supercycles as dissolution cycles at intermedi- 


\section{Tongue of the Ocean}

GS 7705-34 (Droxler et al., 1983)

P 7102-14 (Droxler, 1984)

Exuma Sound

$\triangle$ ODP Hole $633 A$ (this paper)

$\Delta$ ODP Hole 632A (Reymer et al., this vol.)

- Pteropod ratio $=\frac{\text { whole tests }}{\text { whole \& fragmented tests }}$

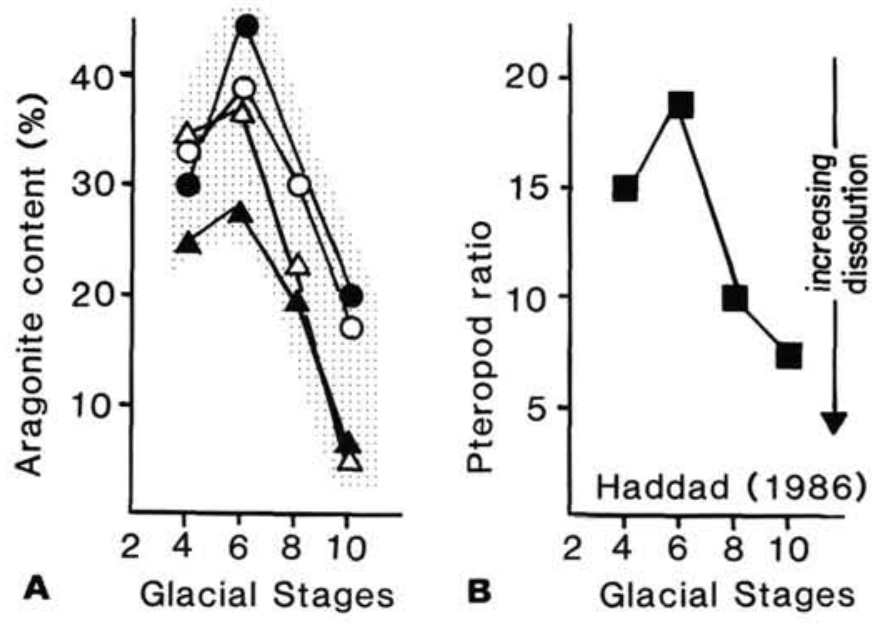

Figure 11. A. Last half of aragonite supercycle recorded in four Bahamian cores by the variations of the average aragonite values for the last four glacial aragonite minima (glacial isotope stages 2 through $4,6,8$, and 10). Note the lowest average values during stage 10 and the highest aragonite values during stage 6. B. Pteropod ratio (whole tests/whole and fragmented tests), possible dissolution index, for the last glacial isotope stages 2 through $4,6,8$, and 10 . Note minimum number of whole pteropod tests (maximum dissolution) during stage 10 and maximum number of whole pteropod tests (minimum dissolution) during stage 6.

ate water depth. Direct evidence is, however, needed to strengthen our interpretation. Haddad (1986), studying pteropod occurrence and degree of preservation, has shown in a core from Northwest Providence Channel (water depth, $675 \mathrm{~m}$ ) that values of the ratio between the number of whole tests over the number of whole and fragmented tests vary downcore. This ratio can be used as a dissolution indicator in analogy with foraminifer studies using whole tests and fragments. We have plotted in Figure 11B Haddad's data for the last four glacial stages, corresponding to the last half of the aragonite supercycle; Stage 10 shows maximum values of pteropod dissolution corresponding to the lowest aragonite minimum values in four other Bahamian cores, whereas Stage 6 shows minimum dissolution values corresponding to the highest values of aragonite minimum in the four cores (see Fig. $11 \mathrm{~A}$ and $\mathrm{B})$.

During the Quaternary, the planktonic oxygen-isotope record correlates well with the aragonite cycles. Some mismatches generally appear at glácial-to-interglacial boundaries, where the aragonite increase lags behind the oxygen-isotope depletion most of the time, or vice versa (Fig. 9). The significance of these lags is incompletely understood, and further studies are needed to positively confirm their existence. These lags could, however, become highly significant in solving the controversy over the origin of the climatically induced aragonite cycles. The question remains whether the cycles reflect a pure aragonite input signal related to bank flooding (i.e., Boardman and Neumann, 1986) or a combination of both an aragonite input and preservation (caused by changing the aragonite saturation level within the water columns in relation to climatically induced variations of the carbonate chemistry in intermediate water masses). We are tempted to interpret these lags between aragonite increase and oxygen depletion by temporary decoupling of aragonite input and preservation/dissolution signal, especially in the case where a (0.5-m.y.) preservation/dissolution supercycle is added to the high-frequency cycles. Statistical analyses of the different signals and further detailed studies of the lags between the different signals need to be developed to address these problems.

\section{Pliocene Aragonite Record}

In spite of the 1.6-m.y.-long hiatus, the incomplete Pliocene record in Hole 633A is somewhat puzzling, since it displays the lowest and the highest values of aragonite content observed in the entire Pliocene-Pleistocene record.

The upper Pliocene sequence of Hole 633A includes only the interval between 2.15 and $1.6 \mathrm{Ma}$. This corresponds to a time just following the onset of major glaciation in the North Atlantic, dated at $2.4 \mathrm{Ma}$ by Shackleton et al. (1984). The Hole 633A sequence is characterized by generally low aragonite content and commonly a total absence of aragonite. In addition, the aragonite variations are irregular. They display no distinct cyclic pattern, although the planktonic oxygen-isotope record for the same interval shows high-frequency and relatively low-amplitude climatic cycles, similar to the early Pleistocene cycles. There is therefore no clear correlation between the oxygen-isotope cycles and the irregular aragonite variations, as was the case later during the early Pleistocene, when aragonite cycles were well developed. In the same upper Pliocene interval, the fluctuations in carbonate content are the largest recorded during the entire Pliocene-Pleistocene, except for the two clay-rich layers in the middle Pleistocene. This observation seems logical because the upper Pliocene interval was deposited just after the onset of the major glaciations in the North Atlantic. Furthermore, carbonate fluctuations are known to be related in the Bahamas, at least during the late Pleistocene, to variable rates of dilution by glacial input of fine terrigenous material transported southward by the Western Boundary Undercurrent (Droxler, 1984). In addition, the carbonate fluctuations correlate well with the oxygenisotope record, with low carbonate values (quartz occurrence) corresponding to glacial heavy oxygen-isotope values. Absence or low content of aragonite and a lack of cyclic pattern in the aragonite content are surprising, since both the oxygen-isotope and the carbonate records show an early-Pleistocene-like glacial cyclic pattern.

The late Pliocene aragonite record can represent either a temporary cutoff of the primary input of bank-derived aragonite or a generally poor preservation (greater dissolution) of the aragonite at the seafloor. The amplitude and frequency of the oxygen-isotope cycles (a proxy to the sea-level curve) remained similar during the late Pliocene and early Pleistocene, whereas the aragonite cycles were initiated only at the Pliocene/Pleistocene boundary. Thus it is difficult to imagine an almost complete cutoff of aragonite input to explain the low values or absence of aragonite during the late Pliocene. On the other hand, in several carbonate curves published by Hays et al. (1969), Saito et al. (1975), and Vincent (1985), the late Pliocene interval centered on the Olduvai Event generally corresponds to one of the most extreme carbonate minima (intense dissolution interval M17) for the entire Pliocene-Pleistocene. We are thus tempted to interpret the low values or absence of aragonite during the late Pliocene as evidence for dissolution of the bank aragonite at the seafloor.

The lower Pliocene sequence of Hole 633A is also incomplete. On the basis of magnetostratigraphy it is estimated to correspond to a time span between 4.5 and $3.75 \mathrm{Ma}$. Besides the presence of authigenic dolomite as a secondary mineral and a 
general occurrence of chalk, both related to early sub-seafloor diagenesis, values of aragonite content are among the highest for the Pliocene-Pleistocene sequence of Hole 633A. The aragonite values remain fairly constant between $\sim 4.50$ to $4.25 \mathrm{Ma}$, a time interval characterized by the highest sedimentation rates $(28 \mathrm{~m} / \mathrm{m} . \mathrm{y}$.) recorded for the Pliocene-Pleistocene. The next interval ( 4.25 to $3.75 \mathrm{Ma}$ ) is characterized by an incremental drop of aragonite and low sedimentation rate, parallel with an enrichment of $\delta^{18} \mathrm{O}$ between 3.9 and $3.75 \mathrm{Ma}$, corresponding to a well-established climatic deterioration (Hodell and Kennett, 1986; Haq et al., 1987) as well as a gradual decrease of carbonate preservation in equatorial Pacific cores (Hays et al., 1969; Saito et al., 1975; Vincent, 1985). Contrary to the large fluctuations of carbonate content in the late Pliocene, the carbonate values during the early Pliocene (prior to the onset of the major glaciations in the North Atlantic) are the highest among the PliocenePleistocene cores and remain mostly constant.

\section{CONCLUSIONS}

The top $55 \mathrm{~m}$ of Hole $633 \mathrm{~A}$ corresponds to the past $4.5 \mathrm{~m} . \mathrm{y}$., including a 1.6-m.y.-long Pliocene hiatus, constrained in time by calcareous-nannofossil biostratigraphy and magnetostratigraphy between 2.15 and $3.75 \mathrm{Ma}$. Downcore variations of aragonite content in the periplatform sequence of Hole $633 \mathrm{~A}$ provide a detailed record of Pliocene-Pleistocene oceanographic changes of intermediate water masses. The aragonite paleoceanographic primary record remains surprisingly unaltered despite such early diagenetic processes as (1) rapid downcore disappearance of magnesian calcite; (2) partial calcite overgrowth and cementation in chalky intervals, more common in the deepest part of the sequence; and (3) ubiquitous occurrence of authigenic dolomite as a secondary mineral in the lower Pliocene.

Twenty-one and one-half (A through V) climatically induced cycles are observed throughout the entire Quaternary (past 1.6 m.y.). They correlate well with a planktonic-foraminifer oxygenisotope curve established from the same set of samples. Each interglacial/glacial cycle starts with a sharp aragonite increase at the deglaciation transition, followed by a gradual aragonite decrease toward the glacial interval. As was well-documented in the Quaternary oxygen-isotope record, high-frequency aragonite cycles (approximately 1 cycle every 50,000 yr) during the early Pleistocene switch to low-frequency (approximately 1 cycle every $100,000 \mathrm{yr}$ ) aragonite cycles during the middle and late Pleistocene. Lower frequency aragonite supercycles (approximately 1 cycle every $0.5 \mathrm{~m} . \mathrm{y}$.) appear in the full aragonite Quaternary record. Their timing matches the low-frequency ( 1 cycle every 0.4 to $0.5 \mathrm{~m} . \mathrm{y}$.) carbonate dissolution/preservation cycle observed mainly in cores from the Pacific Ocean but also in the Indian and North Atlantic oceans.

The low values or absence of aragonite as well as the noncyclic aragonite variations in the late Pliocene ( 2.15 to $1.6 \mathrm{~m}$.y.) are somewhat puzzling, since during the same period early Pleistocene-like oxygen-isotope cycles as well as carbonate-dilution cycles are well developed. The lack of aragonite cycles could be interpreted as particularly poor preservation of the aragonite input at the seafloor during the part of the late Pliocene within the normal Olduvai Event, an interval known in the equatorial Pacific as one with the poorest carbonate preservation during the Pliocene-Pleistocene. The early Pliocene interval between 4.5 and $4.25 \mathrm{Ma}$ is characterized by very high and fairly constant aragonite content and high sedimentation rates $(28 \mathrm{~m} /$ m.y.), and it corresponds to the end of a prolonged warm interglacial interval characterized by good carbonate preservation in the equatorial Pacific Ocean and quite high sea level. The incremental aragonite decrease between 4.25 and $3.75 \mathrm{Ma}$ corresponds to a climatic cooling, to a steplike decrease of carbonate preservation in the equatorial Pacific Ocean, and to a global lowering of sea level.
Because of (1) good correlation between the oxygen-isotope record and the aragonite cycles, (2) occurrence of the aragonite supercycle, (3) characteristic sharp aragonite increases at each aragonite cycle boundary, and (4) generally good correlation between the aragonite variations and the established Pliocene paleoceanographic record (i.e., carbonate preservation record in the equatorial Pacific Ocean), the aragonite variations seem to be much more finely attuned to the global ocean atmosphere carbon system than to only the simple flooding and exposure of shallow carbonate banks. The Quaternary aragonite cycles and supercycles, as well as the Pliocene aragonite variations, are interpreted to represent changes in climatically induced carbonate preservation/dissolution at intermediate water depths of the aragonite bank input, the latter modulated by cyclic bank flooding.

The aragonite record in periplatform ooze will thus become highly valuable in linking the carbonate system between ocean and atmosphere, especially since its primary signal is still preserved back to the early Pliocene. This record will become more global in the next few years through studies in progress on periplatform sequences in the Maldives (Indian Ocean, ODP Leg 115 ), and possibly sequences in Northeast Australia (future ODP drilling proposed on the Queensland Plateau).

\section{ACKNOWLEDGMENTS}

This research was supported in part by a grant from USSAC-JOI to Droxler and Schlager and by funds to Schlager from the Industrial Associates of the Comparative Sedimentology Laboratory of the University of Miami. We thank personnel of the ODP Core Repository of Lamont-Doherty Geological Observatory, particularly Robert Hayman for help during the core sampling, and Tony Barros, Andy Fischer, Terry Hood, Chris Johnson, and Nancy Whittpenn, all at the Rosenstiel School of Marine and Atmospheric Science, University of Miami, for help during sample processing and analyses. We are particularly grateful to Douglas Williams, who made available the Stable Isotope Laboratory at the University of South Carolina, and to Geoffrey A. Haddad, who provided unpublished data from his master's thesis. We had helpful discussions with Wolfgang Schlager, Douglas Williams, and Robert Thunell during the data interpretation. Larry C. Peterson, James A. Austin, Jr., Amanda A. Palmer, and an anonymous reviewer thoroughly reviewed an early draft of the manuscript and made many useful suggestions. Julie Earle at the University of South Carolina typed the first draft. Arista Walters of Rice University typed the final version, and Chingju Liu, also at Rice, drew the final figures on very short notice.

\section{REFERENCES}

Adelseck, C. G., Jr., 1977. Recent and late Pleistocene sediments from the Eastern Equatorial Pacific Ocean: Sedimentation and Dissolution [Ph.D. dissert.]. Univ. California, San Diego.

Austin, J. A., Jr., Schlager, W., et al., 1986. Proc. ODP, Init. Repts., 101: College Station, TX (Ocean Drilling Program).

Berggren, W. A., Kent, D. V., and Van Couvering, J. A., 1985. Neogene geochronology and chronostratigraphy. In Snelling, M. H. (Ed.), Geochronology and the Geologic Time Scale: Geol. Soc. London Mem., 10:111-160.

Birch, G. F., 1979. In progress reports of the year 1978. Cape Town, Univ. Dept. Geol., Mar. Geol. Program, Tech. Rep., 11:122-126.

Boardman, M. R., and Neumann, A. C., 1984. Sources of periplatform carbonates: Northwest Providence Channel, Bahamas. J. Sediment. Petrol., 54:1110-1112.

1985. Sources of periplatform carbonates: Northwest Providence Channel, Bahamas-Reply. J. Sediment. Petrol., 55:929-931.

1986. Reply on "Banktop responses to Quaternary fluctuations in sea level recorded in periplatform sediments." Geology, 14: 1040-1041.

Boardman, M. R., Neumann, A. C., Baker, P. A., Dulin, L. A., Kenter, R. J., Hunter, G. E., and Kiefer, K. B., 1986. Banktop responses to Quaternary fluctuations in sea level recorded in periplatform sediments. Geology, 14:28-31.

Crevello, P. D., and Schlager, W., 1980. Carbonate debris sheets and turbidites, Exuma Sound, Bahamas. J. Sediment. Petrol., 50:11211148.

Crowley, T. J., 1985. Late Quaternary carbonate changes in the North Atlantic and Atlantic/Pacific comparisons. In Sundquist, E. T., and 
Broecker, W. S. (Eds.), The Carbon Cycle and Atmospheric $\mathrm{CO}_{2}$ : Natural Variations, Archean to Present: Geophys. Monogr., 32:271284.

Droxler, A. W., 1984. Late Quaternary glacial cycles in the Bahamian deep basins and in the adjacent Atlantic Ocean [Ph.D. dissert.] Univ. Miami, Coral Gables.

1986a. Worldwide occurrence of periplatform aragonite cycles: a record of climatically induced fluctuations of carbonate saturation in intermediate water masses. 12th Int. Sedimentol. Congr., Canberra, Australia, Abstracts, 86. (Abstract)

1986b. Comment on "Banktop responses to Quaternary fluctuations in sea level recorded in periplatform sediments." Geology, 14:1039-1040.

Droxler, A. W., and Schlager, W., 1985a. Glacial versus interglacial sedimentation rates and turbidite frequency in the Bahamas. Geology, 13:799-802.

1985b. Sources of periplatform carbonates: Northwest Providence Channel, Bahamas-Discussion. J. Sediment. Petrol., 55: 928-929.

Droxler, A. W., Schlager, W., and Whallon, C. C., 1983. Quaternary aragonite cycles and oxygen-isotope record in Bahamian carbonate ooze. Geology, 11:235-239.

Ericson, D. B., and Wollin, G., 1968. Pleistocene climate and chronology in deep-sea sediments. Science, 162:1227-1234.

Haddad, G. A., 1986. A study of carbonate dissolution, stable isotope chemistry and minor element composition of pteropods and forams deposited in the Northwest Providence Channel, Bahamas, during the past 500,000 years [M.S. thesis]. Duke Univ., Durham.

Haq, B. U., Hardenbol, J., and Vail, P. R., 1987. Chronology of fluctuating sea levels since the Triassic. Science, 235:1156-1167.

Harland, W. B., Cox, A. V., Llewellyn, P. G., Pickton, C.A.G., Smith, A. G., and Walters, R., 1982. A Geologic Time Scale: Cambridge (Cambridge Univ. Press).

Hays, J. D., Saito, T., Opdyke, N. D., and Burckle, L. H., 1969. Pliocene-Pleistocene sediments of the equatorial Pacific: their paleomagnetic, biostratigraphic, and climatic record. Geol. Soc. Am. Bull., $80: 1481-1514$.

Hodell, D. A., and Kennett, J. P., 1986. Late Miocene-early Pliocene stratigraphy and paleoceanography of the South Atlantic and southwest Pacific oceans: a synthesis. Paleoceanography, 1:285-311.

Keifer, K. B., 1983. Quaternary climatic cycles recorded in the isotope record of periplatform pelagic deposition: Northwest Providence Channel, Bahamas [M.S. thesis]. Duke Univ., Durham.

Kier, J. S., and Pilkey, O. H., 1971. The influence of sea level changes on sediment carbonate mineralogy, Tongue of the Ocean, Bahamas. Mar. Geol., 11:189-200.

King, P. B., 1969. Tectonic Map of North America: U.S. Geol. Surv.

Milliman, J. D., 1974. Marine Carbonates: New York (Springer-Verlag).
Müller, G., and Gastner, M., 1971. The "Karbonat-Bombe," a simple device for the determination of the carbonate content in sediments, soils and other materials. N. Jahrb. Mineral. Monatsh., 10:466-469.

Peterson, L. C., and Prell, W. L., 1985. Carbonate preservation and rates of climatic change: an $800 \mathrm{Kyr}$ record from the Indian Ocean. In Sundquist, E. T., and Broecker, W. S. (Eds.), The Carbon Cycle and Atmospheric $\mathrm{CO}_{2}$ : Natural Variations, Archean to Present: Geophys. Monogr., 32:251-269.

Prell, W. L., 1982. Oxygen and carbon isotope stratigraphy for the Quaternary of Hole 502B: evidence for two modes of isotopic variability. In Prell, W. L., and Gardner, J. F., et al., Init. Repts. DSDP, 68 : Washington (U.S. Govt. Printing Office), 455-464.

Saito, T., Burckle, L. H., and Hays, J. D., 1975. Late Miocene to Pleistocene biostratigraphy of equatorial Pacific sediments. In Saito, T., and Burckle, L. H. (Eds.), Late Neogene Epoch Boundaries: New York (Micropaleontol. Press), 226-244.

Schlager, W., and James, N. P., 1978. Low-magnesian calcite limestones forming at the deep-sea floor, Tongue of the Ocean, Bahamas. Sedimentology, 15:675-702.

Shackleton, N. J., Backman, J., Zimmerman, H., Kent, D. V., Hal, M. A., and Scientific Party of DSDP Leg 81, 1984. Oxygen isotope calibration of the onset of ice-rafting and history of glaciation in the North Atlantic region. Nature, 307, 5952:620-623.

Shackleton, N. J., and Opdyke, N. D., 1976. Oxygen-isotope and paleomagnetic stratigraphy of Pacific core V28-239, late Pliocene to latest Pleistocene. In Cline, R. M., and Hays, J. D. (Eds.), Investigations of Late Quaternary Paleoceanography and Paleoclimatology: Geol. Soc. Am. Mem., 145:449-464.

Slowey, N. C., 1985. Fine scale acoustic stratigraphy of Northwest Providence Channel, Bahamas [M.S. thesis]. Univ. North Carolina, Chapel Hill.

Supko, P. R., 1963. A quantitative X-ray diffraction method for the mineralogical analysis of carbonate sediments from Tongue of the Ocean [M.S. thesis]. Univ. Miami, Coral Gables.

Thierstein, H. R., Geitzenauer, K. R., Molfino, B., and Shackleton, N. J., 1977. Global synchroneity of Late Quaternary coccolith datum levels: validation by oxygen isotopes. Geology, 5:400-405.

Van Donk, J., 1976. $\mathrm{O}^{18}$ record of the Atlantic Ocean for the entire Pleistocene Epoch. In Cline, R. M., and Hays, J. D. (Eds.), Investigations of Late Quaternary Paleoceanography and Paleoclimatology: Geol. Soc. Am. Mem., 145:147-163.

Vincent, E., 1985. Distribution stratigraphique de la teneur en carbonate dans les sédiments néogènes et quaternaires de l'océan Pacifique. Bull. Soc. Géol. France, 8, t.I, 6:915-924.

Date of initial receipt: 17 December 1986

Date of acceptance: 6 January 1988

Ms 101B-134 
APPENDIX

Oxygen-Isotope Record and Carbonate Mineralogy of the Top Part of Hole 633A Using Globigerinoides sacculifera and $G$. rubra

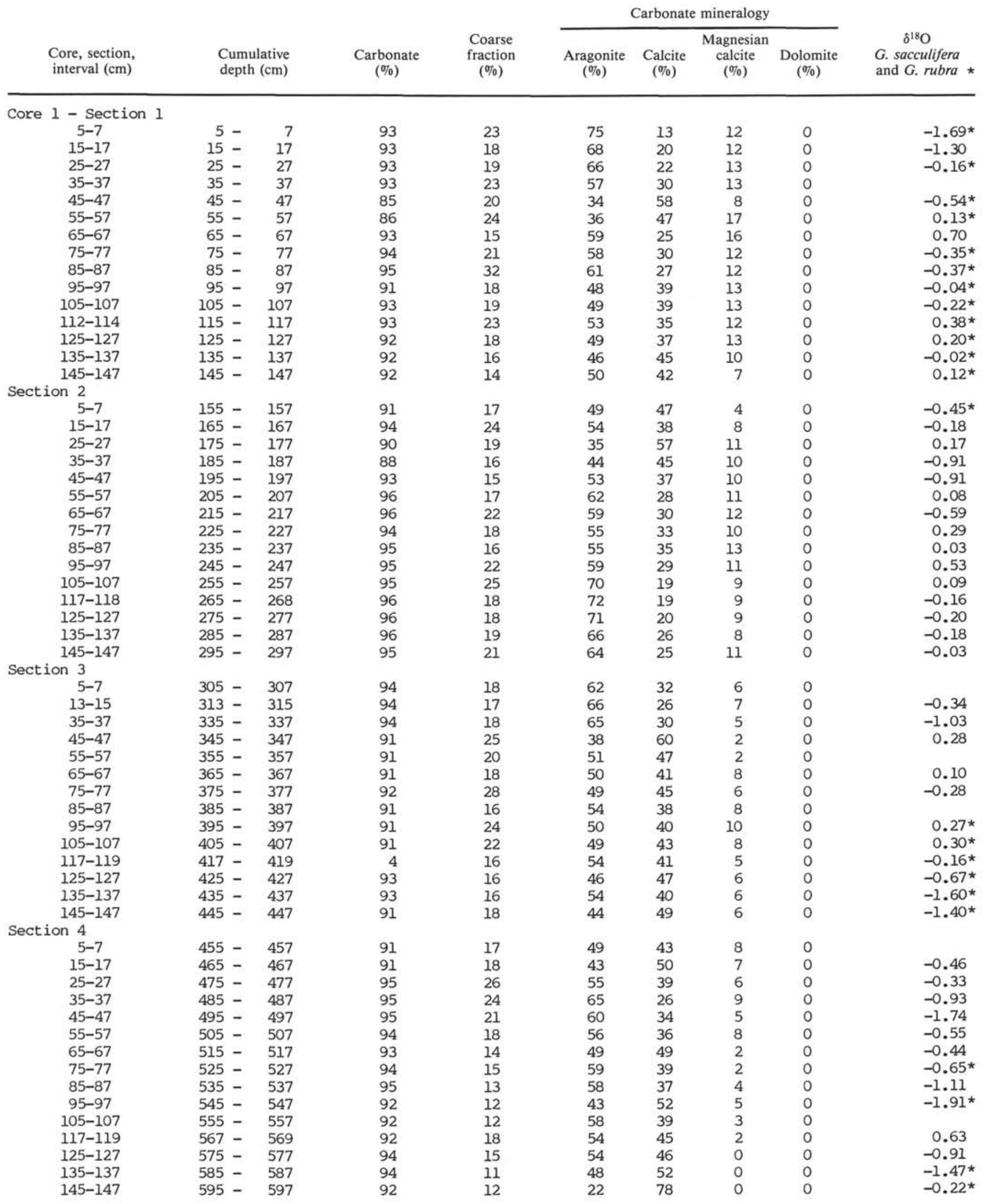


A. W. DROXLER, C. H. BRUCE, W. W. SAGER, D. H. WATKINS

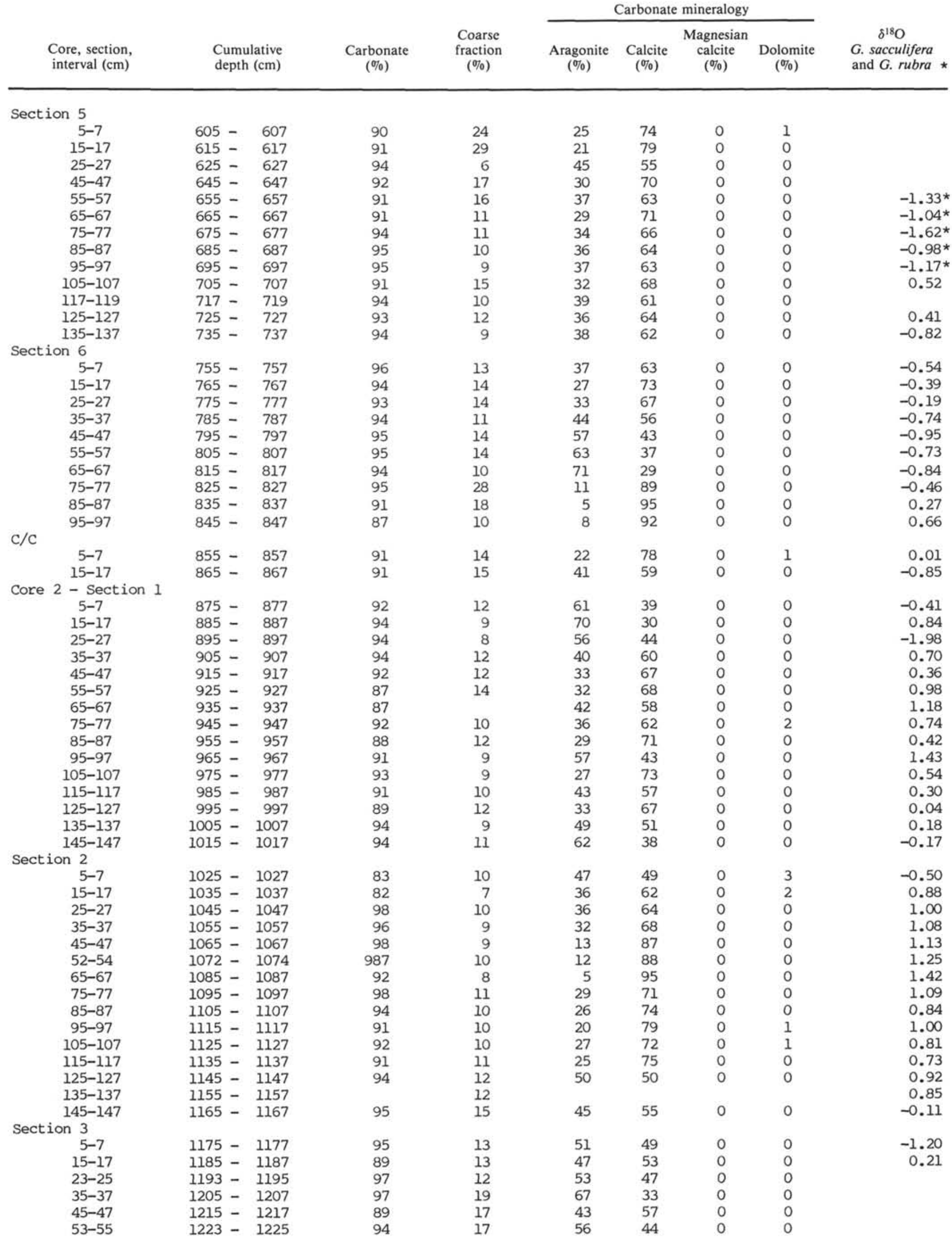




\begin{tabular}{|c|c|c|c|c|c|c|c|c|c|}
\hline \multirow{2}{*}{$\begin{array}{l}\text { Core, section, } \\
\text { interval }(\mathrm{cm})\end{array}$} & \multirow{2}{*}{\multicolumn{2}{|c|}{$\begin{array}{l}\text { Cumulative } \\
\text { depth }(\mathrm{cm})\end{array}$}} & \multirow[b]{2}{*}{$\begin{array}{c}\text { Carbonate } \\
(\%)\end{array}$} & \multirow[b]{2}{*}{$\begin{array}{c}\text { Coarse } \\
\text { fraction } \\
(\%)\end{array}$} & \multicolumn{4}{|c|}{ Carbonate mineralogy } & \multirow[b]{2}{*}{$\begin{array}{l}\quad \delta^{18} \mathrm{O} \\
\text { G. sacculifera } \\
\text { and G. rubra * }\end{array}$} \\
\hline & & & & & $\begin{array}{c}\text { Aragonite } \\
(\%)\end{array}$ & $\begin{array}{c}\text { Calcite } \\
(\%)\end{array}$ & $\begin{array}{l}\text { Magnesian } \\
\text { calcite } \\
(\%)\end{array}$ & $\begin{array}{c}\text { Dolomite } \\
(\%)\end{array}$ & \\
\hline $65-67$ & 1235 & 1237 & 94 & 21 & 43 & 57 & 0 & 0 & \\
\hline $75-77$ & 1245 & 1247 & 94 & 17 & 56 & 43 & 1 & 0 & \\
\hline $85-87$ & 1255 & 1257 & 94 & 17 & 62 & 33 & 5 & 0 & \\
\hline $95-97$ & 1265 & 1267 & 97 & 15 & 69 & 27 & 4 & 0 & -0.75 \\
\hline $105-107$ & 1275 & 1277 & 96 & 18 & 53 & 46 & 1 & 0 & 0.49 \\
\hline $115-117$ & 1285 & 1287 & 92 & 24 & 67 & 30 & 3 & 0 & 0.68 \\
\hline $125-127$ & 1295 & 1297 & 96 & 23 & 56 & 42 & 2 & 0 & 0.18 \\
\hline $135-137$ & 1305 & 1307 & 96 & 19 & 62 & 35 & 3 & 0 & -1.00 \\
\hline $145-147$ & 1315 & 1317 & 95 & 19 & 68 & 31 & 1 & 0 & -0.14 \\
\hline \multicolumn{10}{|l|}{ Section 4} \\
\hline $5-7$ & 1325 & 1327 & 93 & 16 & 69 & 28 & 0 & 0 & -0.46 \\
\hline $15-17$ & 1335 & 1337 & 94 & 15 & 70 & 25 & 5 & 0 & 0.54 \\
\hline $25-27$ & 1345 & 1347 & & 13 & & & & & 0.06 \\
\hline $35-37$ & 1355 & 1357 & 91 & 16 & 70 & 25 & 5 & 0 & -0.28 \\
\hline $45-47$ & 1365 & 1367 & 89 & 11 & 71 & 27 & 2 & 0 & 0.03 \\
\hline $55-57$ & 1375 & 1377 & 96 & 12 & 61 & 39 & 0 & 0 & 0.45 \\
\hline $69-71$ & 1389 & 1391 & 93 & 17 & 30 & 70 & 0 & 0 & 0.92 \\
\hline $75-77$ & 1395 & 1397 & 92 & 17 & 33 & 67 & 0 & 0 & 0.26 \\
\hline $85-87$ & 1405 & 1407 & 89 & 13 & 60 & 35 & 0 & 0 & 0.49 \\
\hline $95-97$ & 1415 & 1417 & 93 & 13 & 21 & 79 & 0 & 0 & 0.49 \\
\hline $105-107$ & 1425 & 1427 & 94 & 18 & 51 & 49 & 0 & 0 & 0.43 \\
\hline $115-117$ & 1435 & 1437 & 77 & 18 & 25 & 75 & 0 & 0 & 1.03 \\
\hline $125-127$ & 1445 & 1447 & 92 & 16 & 56 & 44 & 0 & 0 & 1.21 \\
\hline $135-137$ & $1455-$ & 1457 & 87 & 14 & 40 & 60 & 0 & 0 & 0.74 \\
\hline $145-147$ & 1465 & 1467 & 87 & 17 & 58 & 42 & 0 & 0 & \\
\hline \multicolumn{10}{|l|}{ Section 5} \\
\hline $5-7$ & 1475 & 1477 & 91 & 19 & 49 & 51 & 0 & 0 & 0.45 \\
\hline $15-17$ & $1485-$ & 1487 & 93 & 18 & 44 & 56 & 0 & 0 & -0.37 \\
\hline $25-27$ & 1495 & 1497 & 91 & 17 & 52 & 48 & 0 & 0 & -0.64 \\
\hline $35-37$ & 1505 & 1507 & 94 & 15 & 58 & 42 & 0 & 0 & -0.07 \\
\hline $45-47$ & 1515 & 1517 & 88 & 11 & 65 & 33 & 0 & 2 & -0.69 \\
\hline $53-55$ & 1523 & 1525 & 95 & 13 & 49 & 51 & 0 & 0 & -0.38 \\
\hline $65-67$ & 1535 & 1537 & 94 & 19 & 37 & 63 & 0 & 0 & 0.43 \\
\hline $75-77$ & 1545 & 1547 & 92 & 18 & 34 & 66 & 0 & 0 & -0.18 \\
\hline $85-87$ & 1555 & 1557 & 95 & 10 & 38 & 62 & 0 & 0 & -0.28 \\
\hline $95-97$ & 1565 & 1567 & 96 & 14 & 50 & 50 & 0 & 0 & 0.11 \\
\hline $105-107$ & 1575 & 1577 & 92 & 13 & 39 & 61 & 0 & 0 & 0.12 \\
\hline $115-117$ & 1585 & 1587 & 94 & 15 & 37 & 63 & 0 & 0 & 0.40 \\
\hline $125-127$ & 1595 & 1597 & 95 & 14 & 32 & 68 & 0 & 0 & \\
\hline $135-137$ & 1605 & 1607 & 95 & 17 & 31 & 69 & 0 & 0 & \\
\hline \multicolumn{10}{|l|}{ Section 6} \\
\hline $5-7$ & 1625 & 1627 & 91 & 16 & 34 & 66 & 0 & 0 & 0.80 \\
\hline $15-17$ & 1635 & 1637 & 93 & 17 & 43 & 57 & 0 & 0 & 1.02 \\
\hline $25-27$ & 1645 & 1647 & 94 & 11 & 38 & 62 & 0 & 0 & 1.11 \\
\hline $35-37$ & $1655-$ & 1657 & 95 & 10 & 38 & 62 & 0 & 0 & 0.65 \\
\hline $45-47$ & 1665 & 1667 & 96 & 12 & 45 & 55 & 0 & 0 & 0.62 \\
\hline $53-57$ & 1673 & 1675 & 98 & 10 & 51 & 49 & 0 & 0 & -0.03 \\
\hline $65-67$ & 1685 & 1687 & 97 & 10 & 49 & 51 & 0 & 0 & 0.78 \\
\hline $75-77$ & 1695 & 1697 & 96 & 8 & 50 & 50 & 0 & 0 & 0.34 \\
\hline $85-87$ & 1705 & 1707 & 97 & 10 & 43 & 57 & 0 & 0 & \\
\hline $95-97$ & 1715 & 1717 & 96 & 28 & 26 & 74 & 0 & 0 & -0.11 \\
\hline $105-107$ & 1725 & 1727 & 96 & 10 & 22 & 78 & 0 & 0 & 1.18 \\
\hline $121-123$ & 1741 & 1743 & 93 & 27 & 39 & 61 & 0 & 0 & 1.89 \\
\hline \multicolumn{10}{|l|}{ Core 3 - Section 1} \\
\hline $4-5$ & 1764 & 1766 & 96 & 19 & 40 & 60 & 0 & 0 & 0.53 \\
\hline $16-17$ & 1776 & 1777 & 96 & 18 & 41 & 59 & 0 & 0 & 0.40 \\
\hline $24-25$ & 1784 & 1785 & 96 & 16 & 42 & 58 & 0 & 0 & -0.13 \\
\hline $34-35$ & $1794-$ & 1795 & 94 & 18 & 53 & 47 & 0 & 0 & 0.02 \\
\hline $44-45$ & $1804-$ & 1805 & 95 & 20 & 51 & 44 & 5 & 0 & \\
\hline $54-55$ & 1814 & 1815 & 96 & 17 & 56 & 40 & 4 & 0 & -0.08 \\
\hline $64-65$ & $1824-$ & 1825 & 95 & 14 & 57 & 35 & 8 & 0 & 0.06 \\
\hline $73-74$ & $1833-$ & 1834 & 94 & 26 & 59 & 36 & 5 & 0 & -0.17 \\
\hline $84-85$ & $1844-$ & 1845 & 96 & 16 & 60 & 35 & 5 & 0 & -0.25 \\
\hline $94-95$ & 1854 & 1855 & 96 & 15 & 65 & 32 & 2 & 0 & 0.57 \\
\hline $104-105$ & 1864 & 1865 & 97 & 13 & 62 & 31 & 7 & 0 & -0.34 \\
\hline $114-115$ & $1874-$ & 1875 & 95 & 23 & 59 & 33 & 8 & 0 & -0.36 \\
\hline $124-125$ & $1884-$ & 1885 & 95 & 22 & 62 & 35 & 3 & 0 & 0.23 \\
\hline
\end{tabular}




\begin{tabular}{|c|c|c|c|c|c|c|c|c|c|}
\hline \multirow{2}{*}{$\begin{array}{l}\text { Core, section, } \\
\text { interval }(\mathrm{cm})\end{array}$} & \multirow{2}{*}{\multicolumn{2}{|c|}{$\begin{array}{l}\text { Cumulative } \\
\text { depth }(\mathrm{cm})\end{array}$}} & \multirow[b]{2}{*}{$\begin{array}{c}\text { Carbonate } \\
(\%)\end{array}$} & \multirow[b]{2}{*}{$\begin{array}{c}\text { Coarse } \\
\text { fraction } \\
(\%)\end{array}$} & \multicolumn{4}{|c|}{ Carbonate mineralogy } & \multirow[b]{2}{*}{$\begin{array}{l}\delta^{18} \mathrm{O} \\
\text { G. sacculifera } \\
\text { and } G \text {. rubra * }\end{array}$} \\
\hline & & & & & $\begin{array}{c}\text { Aragonite } \\
(\%)\end{array}$ & $\begin{array}{c}\text { Calcite } \\
(\%)\end{array}$ & $\begin{array}{l}\text { Magnesian } \\
\text { calcite } \\
(\%)\end{array}$ & $\begin{array}{c}\text { Dolomite } \\
(\%)\end{array}$ & \\
\hline $137-138$ & 1897 & $7-1898$ & 95 & 15 & 63 & 31 & 7 & 0 & 0.04 \\
\hline $143-145$ & 1903 & $3-1905$ & 95 & 11 & 62 & 24 & 13 & 0 & \\
\hline \multicolumn{10}{|l|}{ Section 2} \\
\hline $4-5$ & 1914 & $4-1915$ & 94 & 16 & 61 & 35 & 4 & 0 & -0.27 \\
\hline $14-15$ & 1924 & $4-1925$ & 94 & 16 & 72 & 21 & 7 & 0 & -0.63 \\
\hline $24-25$ & 1934 & $4-1935$ & 94 & 15 & 72 & 24 & 3 & 0 & -0.69 \\
\hline $34-35$ & 1944 & $4-1945$ & 95 & 16 & 79 & 14 & 7 & 0 & -0.63 \\
\hline $44-45$ & 1954 & - 1955 & 94 & 14 & 77 & 18 & 5 & 0 & \\
\hline $53-54$ & 1963 & - 1964 & 94 & 13 & 81 & 14 & 5 & 0 & \\
\hline $64-65$ & 1974 & $1-1975$ & 95 & 15 & 76 & 21 & 3 & 0 & \\
\hline $74-75$ & 1984 & -1985 & 95 & 18 & 71 & 24 & 5 & 0 & -1.48 \\
\hline $84-85$ & 1994 & - 1995 & 94 & 18 & 62 & 38 & 0 & 0 & -1.27 \\
\hline $104-105$ & 2014 & -2015 & 88 & 15 & 8 & 92 & 0 & 0 & -1.21 \\
\hline $114-115$ & 2024 & -2025 & 86 & 12 & 19 & 79 & 0 & 2 & -0.42 \\
\hline $124-125$ & 2034 & -2035 & 88 & 18 & 17 & 82 & 0 & 1 & 0.53 \\
\hline $134-135$ & 2044 & -2045 & 90 & 11 & 34 & 66 & 0 & 0 & -1.16 \\
\hline $144-145$ & 2054 & -2055 & 93 & 18 & 35 & 65 & 0 & 0 & -0.38 \\
\hline \multicolumn{10}{|l|}{ Section 3} \\
\hline $4-5$ & 2064 & -2065 & 95 & 18 & 39 & 61 & 0 & 0 & -0.76 \\
\hline $14-15$ & 2074 & -2075 & 95 & 19 & 42 & 58 & 0 & 0 & -0.72 \\
\hline $24-25$ & 2084 & -2085 & 94 & 9 & 67 & 33 & 0 & 0 & -1.54 \\
\hline $43-44$ & 2103 & $3-2104$ & 91 & 13 & 33 & 67 & 0 & 0 & -0.33 \\
\hline $53-54$ & 2113 & $3-2114$ & 92 & 17 & 38 & 62 & 0 & 0 & -1.45 \\
\hline $64-65$ & 2123 & -2124 & 94 & 21 & 30 & 70 & 0 & 0 & -1.08 \\
\hline $74-75$ & 2133 & -2134 & & 21 & & & & & -0.78 \\
\hline $84-85$ & 2144 & $1-2145$ & 96 & 19 & 37 & 63 & 0 & 0 & -0.48 \\
\hline $94-95$ & 2154 & $1-2155$ & 94 & 17 & 37 & 63 & 0 & 0 & 0.63 \\
\hline $104-105$ & 2164 & -2165 & 94 & 20 & 43 & 57 & 0 & 0 & 0.02 \\
\hline $114-115$ & 2174 & -2175 & 94 & 22 & 36 & 64 & 0 & 0 & 0.46 \\
\hline $124-125$ & 2184 & $1-2185$ & 96 & 18 & 42 & 58 & 0 & 0 & 0.58 \\
\hline $134-135$ & 2194 & -2195 & 97 & 18 & 21 & 79 & 0 & 0 & \\
\hline $144-145$ & 2204 & $4-2205$ & 96 & 15 & 35 & 65 & 0 & 0 & 0.63 \\
\hline \multicolumn{10}{|l|}{ Section 4} \\
\hline $5-7$ & 2215 & - 2217 & 93 & 8 & 32 & 68 & 0 & 0 & 0.55 \\
\hline $15-17$ & 2225 & -2227 & 93 & 10 & 46 & 54 & 0 & 0 & -0.85 \\
\hline $25-27$ & 2235 & -2237 & 92 & 11 & 37 & 63 & 0 & 0 & -1.01 \\
\hline $35-37$ & 2245 & -2247 & 91 & 10 & 35 & 65 & 0 & 0 & -1.05 \\
\hline $45-47$ & 2255 & -2257 & 96 & 9 & 37 & 63 & 0 & 0 & -1.82 \\
\hline $55-57$ & 2265 & -2267 & 96 & 10 & 39 & 61 & 0 & 0 & -0.55 \\
\hline $65-67$ & 2275 & -2277 & 96 & 10 & 34 & 66 & 0 & 0 & -0.53 \\
\hline $75-77$ & 2285 & -2287 & 92 & 11 & 41 & 59 & 0 & 0 & -0.88 \\
\hline $85-87$ & 2295 & -2297 & 92 & 12 & 48 & 52 & 0 & 0 & -0.61 \\
\hline $95-97$ & 2305 & -2307 & 91 & 15 & 42 & 58 & 0 & 0 & -0.06 \\
\hline $105-107$ & 2315 & -2317 & 96 & 25 & 45 & 55 & 0 & 0 & 0.70 \\
\hline $115-117$ & 2325 & -2327 & 96 & 17 & 42 & 58 & 0 & 0 & 0.81 \\
\hline $125-127$ & 2335 & -2337 & 96 & 15 & 43 & 57 & 0 & 0 & \\
\hline $135-137$ & 2345 & -2347 & 94 & 16 & 46 & 54 & 0 & 0 & \\
\hline \multicolumn{10}{|l|}{ Section 5} \\
\hline $3-5$ & 2363 & -2365 & 98 & 13 & 59 & 41 & 0 & 0 & -0.11 \\
\hline $10-12$ & 2370 & -2372 & 99 & 15 & 60 & 40 & 0 & 0 & -0.03 \\
\hline $18-20$ & 2378 & -2380 & 96 & 14 & 60 & 40 & 0 & 0 & 0.11 \\
\hline $35-37$ & 2395 & -2397 & 93 & 11 & 15 & 85 & 0 & 0 & 0.50 \\
\hline $45-47$ & 2405 & -2407 & 93 & 10 & 22 & 78 & 0 & 0 & 0.51 \\
\hline $55-57$ & 2415 & -2417 & 93 & 13 & 26 & 74 & 0 & 0 & 0.62 \\
\hline $65-67$ & 2425 & -2427 & 97 & 9 & 44 & 56 & 0 & 0 & 0.07 \\
\hline $75-77$ & 2435 & -2437 & 97 & 11 & 35 & 65 & 0 & 0 & -0.17 \\
\hline $87-89$ & 2447 & -2449 & 93 & 11 & 34 & 66 & 0 & 0 & -0.10 \\
\hline $95-97$ & 2455 & -2457 & 91 & 8 & 33 & 65 & 0 & 2 & 0.03 \\
\hline $105-107$ & 2465 & -2467 & 93 & 10 & 33 & 67 & 0 & 0 & 0.28 \\
\hline $115-117$ & 2475 & -2477 & 95 & 19 & 50 & 49 & 0 & 1 & \\
\hline Section 6 & 2515 & -2517 & 92 & 12 & 42 & 58 & 0 & 0 & -0.55 \\
\hline $15-17$ & 2525 & -2527 & 96 & 14 & 46 & 54 & 0 & 0 & -0.26 \\
\hline $25-27$ & 2535 & -2537 & 97 & 14 & 48 & 52 & 0 & 0 & -0.31 \\
\hline $34-36$ & 2544 & -2546 & 96 & 17 & 56 & 44 & 0 & 0 & -0.53 \\
\hline $45-47$ & 2555 & -2557 & 96 & 17 & 53 & 47 & 0 & 0 & -1.57 \\
\hline $55-57$ & 2565 & -2567 & 97 & 19 & 59 & 41 & 0 & 0 & \\
\hline $69-71$ & 2579 & -2580 & 97 & 25 & 70 & 30 & 0 & 0 & -0.94 \\
\hline
\end{tabular}




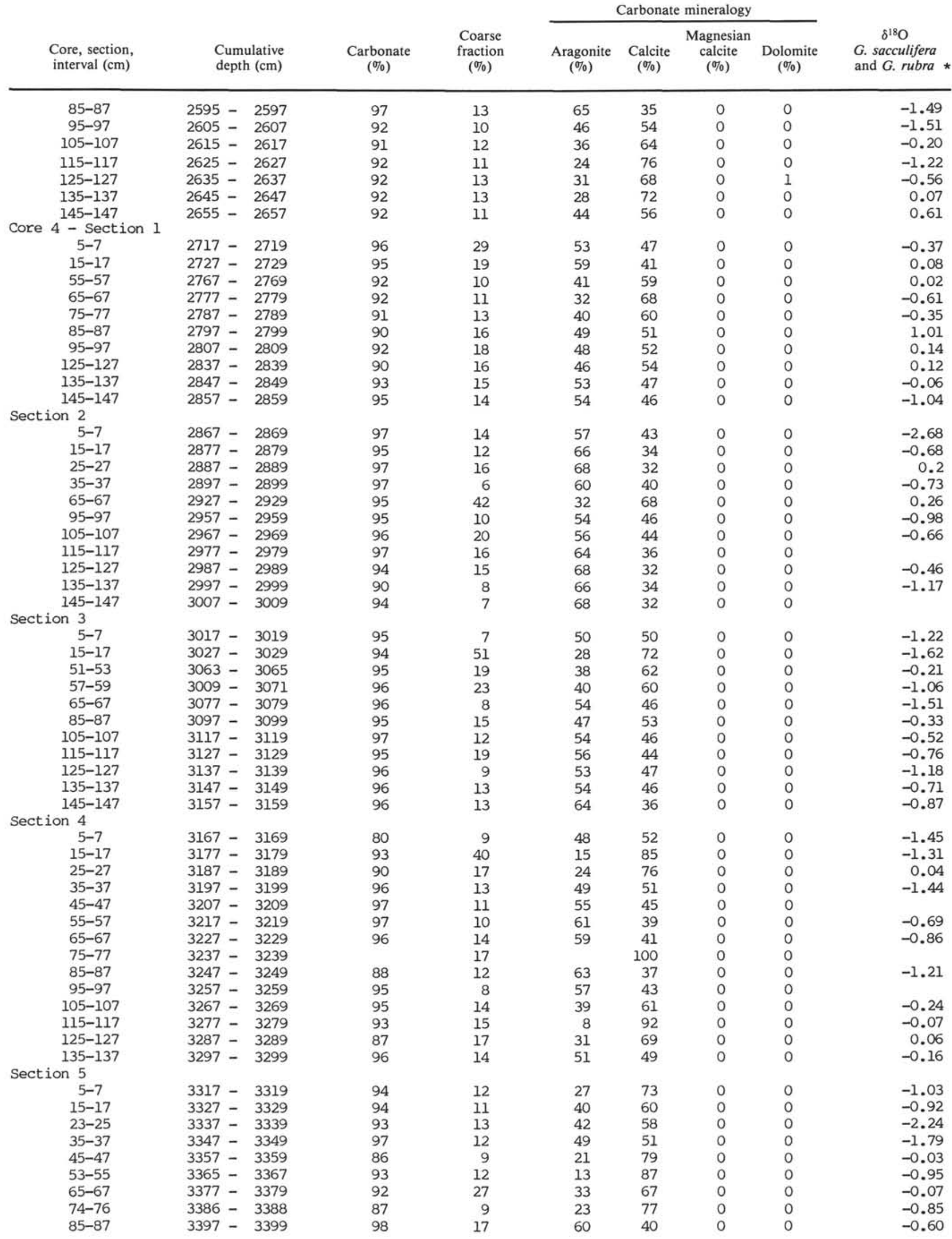


A. W. DROXLER, C. H. BRUCE, W. W. SAGER, D. H. WATKINS

\begin{tabular}{|c|c|c|c|c|c|c|c|c|c|}
\hline \multirow{2}{*}{$\begin{array}{l}\text { Core, section, } \\
\text { interval }(\mathrm{cm})\end{array}$} & \multirow{2}{*}{\multicolumn{2}{|c|}{$\begin{array}{l}\text { Cumulative } \\
\text { depth }(\mathrm{cm})\end{array}$}} & \multirow[b]{2}{*}{$\begin{array}{c}\text { Carbonate } \\
(\%)\end{array}$} & \multirow[b]{2}{*}{$\begin{array}{c}\text { Coarse } \\
\text { fraction } \\
(\%)\end{array}$} & \multicolumn{4}{|c|}{ Carbonate mineralogy } & \multirow[b]{2}{*}{$\begin{array}{l}\quad \delta^{18} \mathrm{O} \\
\text { G. sacculifera } \\
\text { and } G \text {. rubra * }\end{array}$} \\
\hline & & & & & $\begin{array}{c}\text { Aragonite } \\
(\%)\end{array}$ & $\begin{array}{c}\text { Calcite } \\
(\%)\end{array}$ & $\begin{array}{l}\text { Magnesian } \\
\text { calcite } \\
(\%)\end{array}$ & $\begin{array}{c}\text { Dolomite } \\
(\%)\end{array}$ & \\
\hline $95-97$ & 3407 & - 3409 & 94 & 11 & & 100 & 0 & 0 & -1.48 \\
\hline $105-107$ & 3417 & - 3419 & 94 & 21 & 61 & 39 & 0 & 0 & -1.69 \\
\hline $114-116$ & 3426 & -3428 & 94 & 20 & 40 & 60 & 0 & 0 & -0.77 \\
\hline $125-127$ & 3437 & - 3439 & 94 & 16 & 44 & 56 & 0 & 0 & -0.03 \\
\hline $135-137$ & 3447 & - 3449 & 97 & 11 & 61 & 39 & 0 & 0 & -0.15 \\
\hline $145-147$ & 3457 & $7-3459$ & 97 & 7 & 72 & 28 & 0 & 0 & -0.13 \\
\hline \multicolumn{10}{|l|}{ Section 6} \\
\hline $5-7$ & 3467 & $7-3469$ & 97 & 4 & 79 & 21 & 0 & 0 & -1.61 \\
\hline $15-17$ & 3477 & $7-3479$ & 80 & 5 & 71 & 29 & 0 & 0 & -0.73 \\
\hline $25-27$ & 3487 & - 3489 & 95 & 14 & 65 & 35 & 0 & 0 & -0.36 \\
\hline $35-37$ & 3497 & 7 3499 & 86 & 9 & 50 & 50 & 0 & 0 & -0.45 \\
\hline $45-47$ & 3507 & - 3509 & 94 & 69 & 36 & 64 & 0 & 0 & -1.48 \\
\hline $55-57$ & 3517 & - 3519 & 92 & 18 & 35 & 65 & 0 & 0 & -1.48 \\
\hline $69-71$ & 3531 & - 3533 & 97 & 11 & 56 & 44 & 0 & 0 & -0.46 \\
\hline 99-101 & 3561 & -3563 & 95 & 35 & 52 & 48 & 0 & 0 & \\
\hline $121-123$ & 3585 & -3587 & 95 & 10 & 65 & 35 & 0 & 0 & -1.48 \\
\hline $135-137$ & 3597 & - 3599 & 80 & 11 & 16 & 84 & 0 & 0 & 0.13 \\
\hline $145-147$ & 3607 & - 3609 & 85 & 16 & 10 & 90 & 0 & 0 & -0.52 \\
\hline \multicolumn{10}{|l|}{ Section 7} \\
\hline $5-7$ & 3617 & -3619 & & 16 & 7 & 93 & 0 & 0 & \\
\hline Core 5 - Section 1 & & & & & & & & & \\
\hline $15-17$ & 3640 & -3642 & 94 & 26 & 34 & 66 & 0 & 0 & -0.73 \\
\hline $35-37$ & 3660 & -3662 & 92 & 13 & 41 & 59 & 0 & 0 & -0.87 \\
\hline $45-47$ & 3670 & -3672 & 86 & 47 & 16 & 84 & 0 & 0 & 0.46 \\
\hline $55-57$ & 3680 & -3682 & 89 & 16 & 8 & 92 & 0 & 0 & 0.75 \\
\hline $65-67$ & 3690 & -3692 & 93 & 12 & 20 & 80 & 0 & 0 & -1.40 \\
\hline $75-77$ & 3700 & -3702 & 97 & 24 & 36 & 64 & 0 & 0 & -0.49 \\
\hline $85-87$ & 3710 & -3712 & 94 & 13 & 28 & 72 & 0 & 0 & -0.45 \\
\hline $95-97$ & 3720 & $-\quad 3722$ & 95 & 16 & 1 & 99 & 0 & 0 & -0.22 \\
\hline $105-107$ & 3730 & -3732 & 95 & 17 & 0 & 100 & 0 & 0 & -0.44 \\
\hline $115-117$ & 3740 & -3742 & 96 & 14 & 0 & 100 & 0 & 0 & -1.26 \\
\hline $125-127$ & 3750 & -3752 & 95 & 21 & 0 & 100 & 0 & 0 & -0.74 \\
\hline $135-137$ & 3760 & -3762 & 97 & 11 & 6 & 94 & 0 & 0 & 0.51 \\
\hline $145-147$ & 3770 & -3772 & 93 & 8 & 28 & 72 & 0 & 0 & -0.09 \\
\hline \multicolumn{10}{|l|}{ Section 2} \\
\hline $5-7$ & 3780 & -3782 & 91 & 18 & 16 & 84 & 0 & 0 & -0.35 \\
\hline $15-17$ & 3790 & -3792 & 98 & 8 & 51 & 49 & 0 & 0 & -0.51 \\
\hline $25-27$ & 3800 & - 3802 & 97 & 8 & 51 & 49 & 0 & 0 & 0.17 \\
\hline $35-37$ & 3810 & -3812 & 98 & 14 & 28 & 72 & 0 & 0 & 0.28 \\
\hline $45-47$ & 3820 & $-\quad 3822$ & 96 & 42 & 14 & 86 & 0 & 0 & \\
\hline $55-57$ & 3830 & -3832 & 95 & 17 & 14 & 86 & 0 & 0 & -0.24 \\
\hline $65-67$ & 3840 & -3842 & 97 & 11 & & 100 & 0 & 0 & -1.51 \\
\hline $75-77$ & 3850 & $-\quad 3852$ & 94 & 10 & 0 & 100 & 0 & 0 & 0.14 \\
\hline $85-87$ & 3860 & -3862 & 90 & 15 & & 100 & 0 & 0 & \\
\hline 95-97 & 3870 & $-\quad 3872$ & 92 & 19 & & 100 & 0 & 0 & -0.34 \\
\hline $105-107$ & 3880 & -3882 & 98 & 28 & 0 & 100 & 0 & 0 & \\
\hline $115-117$ & 3890 & - 3892 & 95 & 28 & 13 & 87 & 0 & 0 & -0.00 \\
\hline $125-127$ & 3900 & -3902 & 94 & 37 & 0 & 100 & 0 & 0 & -0.93 \\
\hline $135-137$ & 3910 & -3912 & 91 & 18 & 0 & 100 & 0 & 0 & \\
\hline $145-147$ & 3920 & -3922 & 97 & 20 & 0 & 100 & 0 & 0 & -0.65 \\
\hline \multicolumn{10}{|l|}{ Section 3} \\
\hline $5-7$ & 3930 & -3932 & 97 & 13 & 0 & 100 & 0 & 0 & -0.24 \\
\hline $15-17$ & 3940 & -3942 & 97 & 17 & 0 & 100 & 0 & 0 & \\
\hline $23-25$ & 3948 & -3950 & 97 & 17 & 0 & 100 & 0 & 0 & -0.17 \\
\hline $35-37$ & 3960 & -3962 & 97 & 28 & 0 & 100 & 0 & 0 & -0.57 \\
\hline $45-47$ & 3970 & -3972 & 97 & 38 & 0 & 100 & 0 & 0 & -0.49 \\
\hline $55-57$ & 3980 & -3982 & 97 & 36 & 0 & 100 & 0 & 0 & -0.29 \\
\hline $65-67$ & 3990 & -3992 & 99 & 32 & 0 & 100 & 0 & 0 & -0.48 \\
\hline $75-77$ & 4000 & -4002 & 94 & 43 & 0 & 100 & 0 & 0 & 0.89 \\
\hline $85-87$ & 4010 & -4012 & 94 & 42 & 0 & 100 & 0 & 0 & 0.46 \\
\hline $95-97$ & 4020 & -4022 & 95 & 36 & 15 & 85 & 0 & 0 & 0.24 \\
\hline $105-107$ & 4030 & -4032 & 100 & 51 & 18 & 82 & 0 & 0 & 0.17 \\
\hline $115-117$ & 4040 & -4042 & 99 & 43 & 30 & 70 & 0 & 0 & -0.44 \\
\hline $125-127$ & 4050 & -4052 & 100 & 43 & 21 & 79 & 0 & 0 & -0.68 \\
\hline $135-137$ & 4060 & -4062 & 98 & 38 & 29 & 71 & 0 & 0 & -0.32 \\
\hline $145-147$ & 4070 & -4072 & 99 & 57 & 30 & 70 & 0 & 0 & -0.28 \\
\hline
\end{tabular}




\begin{tabular}{|c|c|c|c|c|c|c|c|c|c|}
\hline \multirow{2}{*}{$\begin{array}{l}\text { Core, section, } \\
\text { interval }(\mathrm{cm})\end{array}$} & \multirow{2}{*}{\multicolumn{2}{|c|}{$\begin{array}{l}\text { Cumulative } \\
\text { depth }(\mathrm{cm})\end{array}$}} & \multirow[b]{2}{*}{$\begin{array}{c}\text { Carbonate } \\
(\%)\end{array}$} & \multirow[b]{2}{*}{$\begin{array}{c}\text { Coarse } \\
\text { fraction } \\
(\%)\end{array}$} & \multicolumn{4}{|c|}{ Carbonate mineralogy } & \multirow[b]{2}{*}{$\begin{array}{l}{ }^{18} \mathrm{O} \\
\text { G. sacculifera } \\
\text { and G. rubra * }\end{array}$} \\
\hline & & & & & $\begin{array}{c}\text { Aragonite } \\
(\%)\end{array}$ & $\begin{array}{c}\text { Calcite } \\
(\%)\end{array}$ & $\begin{array}{l}\text { Magnesian } \\
\text { calcite } \\
(\%)\end{array}$ & $\begin{array}{c}\text { Dolomite } \\
(\%)\end{array}$ & \\
\hline \multicolumn{10}{|l|}{ Section 4} \\
\hline $5-7$ & 4080 & -4082 & 96 & 30 & 48 & 52 & 0 & 0 & -1.30 \\
\hline $15-17$ & 4090 & -4092 & 93 & 20 & 49 & 51 & 0 & 0 & -0.02 \\
\hline $25-27$ & 4100 & -4102 & 96 & 24 & 35 & 65 & 0 & 0 & -1.07 \\
\hline $35-37$ & 4110 & -4112 & 92 & 15 & 47 & 53 & 0 & 0 & -0.99 \\
\hline $45-47$ & 4120 & -4122 & 95 & 18 & 38 & 62 & 0 & 0 & -0.70 \\
\hline $55-57$ & 4130 & -4132 & 96 & 41 & 25 & 75 & 0 & 0 & -1.70 \\
\hline $65-67$ & 4140 & -4142 & 93 & 52 & 14 & 86 & 0 & 0 & -0.66 \\
\hline $75-77$ & 4150 & -4152 & 93 & 53 & 0 & 100 & 0 & 0 & -0.56 \\
\hline $95-97$ & 4170 & -4172 & 94 & 49 & 0 & 100 & 0 & 0 & -0.30 \\
\hline $105-107$ & 4180 & -4182 & 89 & 27 & 0 & 100 & 0 & 0 & 0.13 \\
\hline $115-117$ & 4190 & -4192 & 90 & 37 & 0 & 100 & 0 & 0 & -0.38 \\
\hline $125-127$ & 4200 & -4202 & 90 & 23 & 0 & 100 & 0 & 0 & -0.68 \\
\hline $135-137$ & 4210 & -4212 & 84 & 26 & 0 & 100 & 0 & 0 & -0.27 \\
\hline $145-147$ & 4220 & -4222 & 92 & 28 & 0 & 100 & 0 & 0 & -0.27 \\
\hline \multicolumn{10}{|l|}{ Section 5} \\
\hline $4-5$ & 4229 & $9-4230$ & 97 & 15 & 0 & 100 & 0 & 0 & 0.33 \\
\hline $14-15$ & 4239 & - 4240 & 98 & 19 & 0 & 100 & 0 & 0 & 0.15 \\
\hline $24-25$ & 4249 & - 4250 & 96 & 15 & 0 & 100 & 0 & 0 & -0.05 \\
\hline $34-35$ & 4259 & $9-4260$ & 96 & 12 & & 100 & 0 & 0 & 0.22 \\
\hline $43-44$ & 4268 & $3-4269$ & 97 & 15 & 7 & 93 & 0 & 0 & -0.07 \\
\hline $53-54$ & 4279 & $9-4280$ & 94 & 16 & 0 & 100 & 0 & 0 & 0.02 \\
\hline $64-65$ & 4289 & - 4290 & 93 & 14 & 0 & 100 & 0 & 0 & \\
\hline $74-75$ & 4299 & - 4300 & 95 & 14 & 1 & 99 & 0 & 0 & -0.42 \\
\hline $84-85$ & 4309 & $9-4310$ & 98 & 12 & & 100 & 0 & 0 & \\
\hline $93-94$ & 4318 & $3-4319$ & 98 & 12 & 0 & 100 & 0 & 0 & \\
\hline $104-105$ & 4329 & -4330 & 93 & 23 & 0 & 100 & 0 & 0 & 0.51 \\
\hline $115-116$ & 4340 & -4341 & 91 & 15 & 0 & 100 & 0 & 0 & -0.29 \\
\hline $124-125$ & 4349 & -4350 & 90 & 18 & 0 & 100 & 0 & 0 & 0.24 \\
\hline $134-135$ & 4359 & - 4360 & 93 & 18 & 0 & 100 & 0 & 0 & \\
\hline \multicolumn{10}{|l|}{ Section 6} \\
\hline $14-15$ & 4389 & - 4390 & 96 & 13 & 24 & 70 & 0 & 6 & \\
\hline $24-25$ & 4399 & -4400 & 96 & 18 & 32 & 51 & 0 & 17 & 0.20 \\
\hline $34-35$ & 4409 & 7- 4410 & 97 & 10 & & 68 & 0 & 32 & -0.16 \\
\hline $44-45$ & 4419 & -4420 & 97 & 10 & & 78 & 0 & 22 & 0.20 \\
\hline $54-56$ & 4429 & -4430 & 97 & 14 & 27 & 60 & 0 & 13 & \\
\hline $64-65$ & 4439 & -4440 & 97 & 10 & 18 & 66 & 0 & 16 & -0.19 \\
\hline $74-75$ & 4449 & -4450 & 98 & 14 & 18 & 67 & 0 & 15 & -1.07 \\
\hline $84-85$ & 4459 & - 4460 & 97 & 11 & 31 & 57 & 0 & 12 & \\
\hline $94-95$ & 4469 & -4470 & 97 & 11 & 30 & 60 & 0 & 10 & -0.08 \\
\hline $104-105$ & 4479 & - 4480 & 99 & 10 & 22 & 71 & 0 & 7 & -0.36 \\
\hline $114-115$ & 4489 & - 4490 & 99 & 9 & & 89 & 0 & 11 & -0.17 \\
\hline $124-125$ & 4500 & -4501 & 99 & 17 & 19 & 78 & 0 & 3 & -0.38 \\
\hline $135-136$ & 4510 & -4511 & 98 & 11 & 19 & 72 & 0 & 9 & -0.20 \\
\hline $146-147$ & 4521 & - 4522 & 99 & 7 & 29 & 66 & 0 & 5 & -0.39 \\
\hline \multicolumn{10}{|l|}{ Section 7} \\
\hline $4-5$ & 4529 & - 4530 & 95 & 9 & 35 & 58 & 0 & 7 & -0.18 \\
\hline $14-15$ & 4539 & -4540 & 95 & 9 & 34 & 58 & 0 & 7 & 0.14 \\
\hline $24-25$ & 4549 & -4550 & 97 & 10 & 34 & 60 & 0 & 6 & 0.21 \\
\hline $34-35$ & 4559 & - 4560 & 98 & 8 & 37 & 57 & 0 & 7 & \\
\hline $44-45$ & 4569 & - 4570 & 98 & 12 & 41 & 52 & 0 & 7 & 0.03 \\
\hline Core 6 - Section & & & & & & & & & \\
\hline $4-5$ & 4589 & - 4590 & 96 & 7 & 38 & 57 & 0 & 5 & \\
\hline $14-15$ & 4599 & $9-4600$ & 96 & 9 & 27 & 69 & 0 & 3 & \\
\hline $24-25$ & 4609 & $9-4610$ & 96 & 10 & 36 & 59 & 0 & 4 & 0.66 \\
\hline $\begin{array}{l}34-35 \\
44-45\end{array}$ & $\begin{array}{l}4619 \\
4629\end{array}$ & $\begin{array}{l}9-4620 \\
-4630\end{array}$ & $\begin{array}{l}98 \\
96\end{array}$ & $\frac{11}{15}$ & $\begin{array}{l}42 \\
42\end{array}$ & $\begin{array}{l}53 \\
53\end{array}$ & $\begin{array}{l}0 \\
0\end{array}$ & $\begin{array}{l}5 \\
6\end{array}$ & -0.18 \\
\hline $53-54$ & 4638 & $3-4639$ & 96 & 11 & 51 & 43 & 0 & 6 & $\begin{array}{r}0.15 \\
-0.12\end{array}$ \\
\hline $64-65$ & 4649 & $9-4650$ & 98 & 10 & 54 & 40 & 0 & 6 & -0.66 \\
\hline $73-74$ & 4658 & $8-4659$ & 96 & 13 & 47 & 48 & 0 & 5 & -0.23 \\
\hline $83-84$ & 4668 & $3-4669$ & 98 & 14 & 40 & 56 & 0 & 4 & -0.83 \\
\hline 93-94 & 4678 & $8-4679$ & 99 & 12 & 31 & 67 & 0 & 2 & -0.10 \\
\hline $103-104$ & 4688 & $8-4689$ & 98 & 10 & 51 & 45 & 0 & 4 & -1.48 \\
\hline $113-114$ & 4698 & $8-4699$ & 99 & 12 & 51 & 46 & 0 & 3 & \\
\hline $123-124$ & 4708 & $3-4709$ & 98 & 10 & 57 & 40 & 0 & 3 & \\
\hline Section 2 & & & & & & & & & \\
\hline $3-4$ & 4738 & $3-4740$ & 95 & 9 & 57 & 41 & 0 & 1 & \\
\hline
\end{tabular}


A. W. DROXLER, C. H. BRUCE, W. W. SAGER, D. H. WATKINS

\begin{tabular}{|c|c|c|c|c|c|c|c|c|c|}
\hline \multirow{2}{*}{$\begin{array}{l}\text { Core, section, } \\
\text { interval }(\mathrm{cm})\end{array}$} & \multirow{2}{*}{\multicolumn{2}{|c|}{$\begin{array}{l}\text { Cumulative } \\
\text { depth }(\mathrm{cm})\end{array}$}} & \multirow[b]{2}{*}{$\begin{array}{c}\text { Carbonate } \\
(\%)\end{array}$} & \multirow[b]{2}{*}{$\begin{array}{c}\text { Coarse } \\
\text { fraction } \\
(\%)\end{array}$} & \multicolumn{4}{|c|}{ Carbonate mineralogy } & \multirow[b]{2}{*}{$\begin{array}{l}\delta^{18} \mathrm{O} \\
\text { G. sacculifera } \\
\text { and } G \text {. rubra * }\end{array}$} \\
\hline & & & & & $\begin{array}{l}\text { Aragonite } \\
(\%)\end{array}$ & $\begin{array}{c}\text { Calcite } \\
(\%)\end{array}$ & $\begin{array}{l}\text { Magnesian } \\
\text { calcite } \\
(\%)\end{array}$ & $\begin{array}{c}\text { Dolomite } \\
(\%)\end{array}$ & \\
\hline $13-14$ & 4748 & $3-4749$ & 97 & 11 & 57 & 41 & 0 & 2 & \\
\hline $24-25$ & 4759 & $9-4760$ & 97 & 10 & 50 & 49 & 0 & 1 & \\
\hline $33-34$ & 4768 & $3-4769$ & 96 & 14 & 52 & 45 & 0 & 2 & \\
\hline $43-44$ & 4778 & $8-4779$ & 96 & 11 & 53 & 46 & 0 & 3 & \\
\hline $53-54$ & 4788 & $8-4789$ & 97 & 9 & 42 & 55 & 0 & 3 & \\
\hline $63-64$ & 4798 & $3-4799$ & 96 & 9 & 41 & 57 & 0 & 1 & \\
\hline $73-74$ & 4808 & $8-4809$ & 97 & 16 & 38 & 60 & 0 & 2 & \\
\hline $84-85$ & 4819 & $9-4820$ & 99 & 20 & 34 & 63 & 0 & 3 & \\
\hline $94-95$ & 4829 & $9-4830$ & 98 & 11 & 42 & 54 & 0 & 3 & \\
\hline $104-5$ & 4839 & $9-4840$ & 97 & 9 & 35 & 62 & 0 & 3 & \\
\hline $115-16$ & 4850 & -4851 & 97 & 8 & 41 & 57 & 0 & 2 & \\
\hline $124-25$ & 4859 & $9-4860$ & 98 & 8 & 38 & 59 & 0 & 3 & \\
\hline $133-34$ & 4868 & $8-4869$ & 98 & 12 & 32 & 65 & 0 & 3 & \\
\hline $144-145$ & 4879 & $9-4880$ & 98 & 18 & 31 & 65 & 0 & 4 & \\
\hline \multicolumn{10}{|l|}{ Section 3} \\
\hline $5-7$ & 4890 & - 4892 & 95 & 46 & 41 & 63 & 0 & 5 & \\
\hline $15-17$ & 4900 & -4902 & 93 & 13 & 34 & 60 & 0 & 6 & \\
\hline $23-25$ & 4908 & $8-4910$ & 93 & 9 & 41 & 54 & 0 & 6 & \\
\hline $35-32$ & 4920 & -4922 & 93 & 12 & 52 & 42 & 0 & 6 & \\
\hline $45-47$ & 4930 & - 4932 & 93 & 11 & 43 & 53 & 0 & 5 & \\
\hline $55-57$ & 4940 & - 4942 & 93 & 12 & 51 & 44 & 0 & 5 & \\
\hline $65-67$ & 4950 & b - 4952 & 94 & 11 & 53 & 42 & 0 & 5 & \\
\hline $75-77$ & 4960 & - 4962 & 93 & 15 & 59 & 35 & 0 & 6 & \\
\hline $85-87$ & 4970 & -4972 & 93 & 12 & 63 & 32 & 0 & 5 & \\
\hline $95-97$ & 4980 & D 4982 & 95 & 10 & 51 & 45 & 0 & 4 & \\
\hline $105-107$ & 4990 & - 4996 & 96 & 41 & 42 & 55 & 0 & 3 & \\
\hline $115-117$ & 5000 & -5002 & 97 & 35 & 35 & 61 & 0 & 4 & \\
\hline $125-127$ & 5010 & -5012 & 97 & 56 & 48 & 48 & 0 & 4 & \\
\hline $135-137$ & 5020 & -5022 & 96 & 51 & 51 & 43 & 0 & 6 & \\
\hline $145-147$ & 5030 & - 5032 & 95 & 39 & 54 & 41 & 0 & 5 & \\
\hline \multicolumn{10}{|l|}{ Section 4} \\
\hline $5-7$ & 5040 & -5042 & 96 & 56 & 48 & 46 & 0 & 6 & \\
\hline $15-17$ & 5050 & -5052 & 97 & 42 & 54 & 40 & 0 & 7 & \\
\hline $25-27$ & 5060 & -5062 & 98 & 47 & 61 & 33 & 0 & 6 & \\
\hline $45-47$ & 5080 & - 5082 & 97 & 52 & 62 & 38 & 0 & 6 & \\
\hline $55-57$ & 5090 & -5092 & 97 & 61 & 58 & 37 & 0 & 5 & \\
\hline $65-67$ & 5100 & -5102 & 96 & 54 & 61 & 34 & 0 & 5 & \\
\hline $75-77$ & 5110 & -5112 & 97 & 57 & 63 & 31 & 0 & 6 & \\
\hline $85-87$ & 5120 & -5122 & 98 & 42 & 69 & 23 & 0 & 7 & \\
\hline $95-97$ & 5130 & -5132 & 97 & 53 & 64 & 31 & 0 & 5 & \\
\hline $105-107$ & 5140 & -5142 & 98 & 56 & 58 & 37 & 0 & 5 & \\
\hline $115-117$ & 5150 & -5152 & 98 & 62 & 61 & 32 & 0 & 7 & \\
\hline $125-127$ & 5160 & -5162 & 98 & 52 & 60 & 33 & 0 & 7 & \\
\hline $135-137$ & 5170 & -5172 & 98 & 52 & 62 & 32 & 0 & 6 & \\
\hline \multicolumn{10}{|l|}{ Section 5} \\
\hline $4-5$ & 5189 & $9-5190$ & 97 & 47 & 65 & 27 & 0 & 8 & \\
\hline $54-56$ & 5239 & $9-5241$ & 96 & 55 & 71 & 22 & 0 & 8 & \\
\hline $65-67$ & 5250 & -5252 & 97 & 56 & 69 & 25 & 0 & 6 & \\
\hline $75-77$ & 5260 & -5262 & 98 & 49 & 68 & 25 & 0 & 7 & \\
\hline $85-87$ & 5270 & -5272 & 97 & 50 & 70 & 24 & 0 & 6 & \\
\hline $95-97$ & 5880 & -5882 & 98 & 55 & 64 & 30 & 0 & 7 & \\
\hline \multicolumn{10}{|l|}{ Section 6} \\
\hline $5-7$ & 5340 & -5346 & 97 & 52 & 68 & 25 & 0 & 6 & \\
\hline $25-27$ & 5360 & -5362 & 97 & 60 & 66 & 28 & 0 & 6 & \\
\hline $45-47$ & 5380 & -5382 & 96 & 49 & 56 & 39 & 0 & 5 & \\
\hline $65-67$ & 5400 & -5402 & 96 & 57 & 64 & 29 & 0 & 7 & \\
\hline $85-87$ & 5420 & -5422 & 96 & 56 & 71 & 33 & 0 & 7 & \\
\hline $125-127$ & 5460 & -5462 & 95 & 57 & 62 & 33 & 0 & 5 & \\
\hline $145-147$ & 5480 & -5482 & 97 & $80(1)$ & 51 & 45 & 0 & 4 & \\
\hline $5-7$ & 5490 & -5492 & 96 & 39 & 58 & 35 & 0 & 7 & \\
\hline $25-27$ & 5510 & -5512 & 95 & 33 & 65 & 29 & 0 & 6 & \\
\hline $45-47$ & 5530 & -5532 & 97 & 54 & 60 & 35 & 0 & 5 & \\
\hline
\end{tabular}

